\title{
Fish kills linked to a toxic ambush-predator dinoflagellate: distribution and environmental conditions
}

\author{
JoAnn M. Burkholder, Howard B. Glasgow Jr, Cecil W. Hobbs \\ Department of Botany, Box 7612, North Carolina State University, Raleigh, North Carolina 27695-7612, USA
}

\begin{abstract}
The toxic ambush-predator dinoflagellate Pfiesteria piscicida gen. et sp. nov. has been implicated as a causative agent of major fish kills in estuarine ecosystems of the southeastern United States. $P$. piscicida is stimulated by fresh fish secreta, and it was lethal to all 19 species of native and exotic finfish and shellfish bioassayed in culture; thus far in field and aquaculture kills linked to the dinoflagellate, 13 additional fish species have been affected. Field data in combination with confirming laboratory bioassays documented toxicity at temperatures ranging from 12 to $33^{\circ} \mathrm{C}$, with most outbreaks occurring at $26^{\circ} \mathrm{C}$ or higher. $P$. piscicida also exhibits wide salinity tolerance; it was lethal to fish from 0 to $35 \mathrm{ppt}$ in calcareous waters, with an optimum salinity for growth and toxic activity at $15 \mathrm{ppt}$. It was toxic to fish day or night $\left(\geq 250\right.$ toxic zoospores $\left.\mathrm{ml}^{-1}\right)$ without an apparent light optimum, in

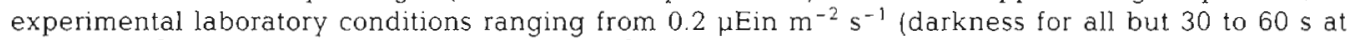

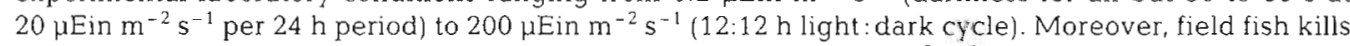
have occurred in darkness and at light intensities up to $2400 \mu \mathrm{Ein} \mathrm{m}^{-2} \mathrm{~s}^{-1}$. Through direct microscope counts of water samples, confirmed identifications with scanning electron microscopy, and confirmed toxic activity in bioassays, $P$. piscicida was implicated as the causative agent of $52 \pm 7 \%$ of the major fish kills (affecting $10^{3}$ to $10^{9}$ fish from May 1991 to November 1993) on an annual basis in North Carolina estuaries and coastal waters. Since their discovery in natural habitat during 1991, Pfiesteria-like species also have been tracked to eutrophic sudden-death fish kill sites in estuaries, coastal waters, and aquaculture facilities from the mid-Atlantic through the Gulf Coast. Toxic ambush-predator dinoflagellates likely are widespread in warm temperate/subtropical regions, acting as significant but often undetected sources of fish mortality and disease.
\end{abstract}

KEY WORDS: Fish kills - Estuaries Pfiesteria - Toxic dinoflagellates

\section{INTRODUCTION}

A toxic dinoflagellate with ambush-predator behavior and a complex life cycle recently was implicated as a causative agent of major fish kills in estuaries of the southeastern United States (Burkholder et al. 1992). Pfiesteria piscicida (gen. et sp. nov.; taxonomy to be proposed by K. A. Steidinger et al.j, which represents a new family, genus and species of dinoflagellate, was first observed as a contaminant of unknown origin in finfish cultures (Smith et al. 1988, Noga et al. 1993), and was discovered at a fish kill in estuarine habitat during 1991 (Burkholder et al. 1992).

Detection of unknown substances secreted by schools of finfish stimulates zoospores of Pfiesteria pis- cicida to emerge from benthic cysts or amoeboid stages (Burkholder et al. 1995). As the chemosensory stimulation increases, zoospores develop the capacity for toxin production. These toxic flagellated vegetative cells (or toxic zoospores, TZs) maintain a morphology similar to that of the nontoxic zoospores, but produce an exotoxin(s) that narcotizes finfish, sloughs the fish epidermis, and causes formation of open ulcerative lesions (Noga et al. 1995). The dinoflagellates consume bits of epidermal tissue and blood cells from affected fish, while also engulfing available phytoplankton (Burkholder \& Glasgow 1995). In addition, they produce gametes that complete sexual fusion in the presence of dying fish. The gametes feed saprotrophically on protein hydrolysates and phagocytize bacteria (Glasgow \& 
Burkholder 1993). Upon fish death, TZs and planozygotes form mostly nontoxic amoeboid stages, or encyst and descend back to the sediments. Alternatively, in the absence of live fish, gametes and TZs revert to nontoxic zoospores that maintain activity in phosphateenriched waters, especially when flagellated algal prey are abundant (Burkholder \& Glasgow 1995, Burkholder et al. 1995).

In maintaining an array of active benthic amoebae as well as planktonic flagellates, toxic ambush-predator dinoflagellates differ markedly from red tide dinoflagellates and the bloom-forming 'hidden flora' that appear in high abundance to cause massive fish death (Smayda 1989, 1992, Culotta 1992). By contrast, the lethal stages of toxic ambush predators include both flagellated and amoeboid forms that are usually ephemeral in the water column, with toxic outbreaks lasting less than $24 \mathrm{~h}$ (Burkholder et al. 1992). Because they often represent a minor component of the phytoplankton community during toxic outbreaks, they rarely are detected by water discoloration (NC DNRCD 1987, 1988, 1989, NC DEHNR 1990a, 1991, 1992, unpubl, records, Burkholder et al. 1992). Production of high quantities of lipophilic exotoxin(s) (D Baden, Univ. Miami, unpubl. data), nonetheless, enables relatively low cell densities to be highly lethal to fish.

The discovery of toxic ambush predators has begun to alter paradigms about estuarine dinoflagellates, even at the fundamental level of discerning the major players. Until we learned about the complex life cycle of Pfiesteria-like species, multiple filose (filipodial or 'star'), lobose (lobopodial), and heliozoan amoebae in estuarine habitat were not recognized as dinoflagellates. These widespread forms likely were identified, instead, as belonging among 3 or more genera of amoebae without dinoflagellate linkages (e.g. Bovee \& Sawyer 1979). The overall function of ambush-predator dinoflagellates - including both toxic and nontoxic forms - in the food webs of shallow eutrophic estuaries has not been determined. In the present research, our objectives were to (1) assess the potential significance of the representative toxic ambush predator Pfiesteria piscicida as a causative agent of major estuarine fish kills, including examination of environmental conditions during kill events; (2) experimentally determine optimal physical factors conducive to growth of dominant stages in its life cycle; (3) assay susceptibility of an array of finfish and shellfish species to its lethal toxin(s); and (4) examine its geographic range in the mid-Atlantic and southeastern United States. This information is contributed toward the ultimate goal of predicting outbreaks of toxic ambushpredator dinoflagellates and mitigating their effects on coastal fisheries.

\section{MATERIALS AND METHODS}

Study area. With assistance from the North Carolina Division of Marine Fisheries (NC DMF), the North Carolina Division of Environmental Management (NC DEM), and concerned citizens, we sampled inprogress fish kills from several estuaries within the Albemarle-Pamlico Estuarine System, North Carolina (Fig 1). This shallow, turbid, wind-mixed lagoon represents the second largest estuary by aerial extent in the United States (Epperly \& Ross 1986). Two of its largest tributary rivers, the Neuse and the Pamlico Imean depth of each system ca 2.5 to $3.0 \mathrm{~m}$ i flushing rates $30 \mathrm{~d}$ (Neuse) to $100 \mathrm{~d}$ (Pamlico) under low-flow conditions in summer; Copeland et al. 1984, Epperly \& Ross 1986, Stanley 1992], were the central focus of this research. Both estuaries have been classified as nutrient-sensitive waters by NC DEM; by the early 1980 s some locations had sustained sufficient nutrient loading to support nuisance algal blooms and oxygen deficits, with chlorophyll a seasonally exceeding the State standard (40 $\mathrm{ug} \mathrm{l}^{-1}$; NC DEHNR 1990b).

Although the 2 estuaries are in close proximity, the Pamlico differs from the Neuse in that it lies on a geological phosphorus formation. Adjacent to the lower Pamlico Estuary on South Creek, Texasgulf Chemical Company operates the largest phosphorus mine in the world and discharged ca 2500 metric tons of phosphorus daily from the late 1960 s to 1992 . This point source has now been reduced by more than $90 \%$, but it represented ca $50 \%$ of the total phosphorus loading to the Pamlico Estuary during that period (NC DEHNR $1990 b)$. In the South Creek area, phosphate ranged from ca 300 to $>600 \mu \mathrm{g} \mathrm{PO}_{4}{ }^{3-}-\mathrm{P} \mathrm{I}^{-1}$ during summer low-flow conditions (Stanley 1987). Since phosphorus reductions were achieved by Texasgulf in late 1992, phosphate in both the Pamlico and Neuse sampling areas generally has ranged from ca 50 to $120 \mu \mathrm{g}$ $\mathrm{PO}_{4}{ }^{3-}-\mathrm{P}^{-1}$ (NC DEHNR unpubl. records, J.M.B. \& H.B.G. unpubl. data). The low flushing rates and shallow, wind-mixed character of the Pamlico and Neuse, and seasonally high activity of bottom-disturbing fishing practices such as crab trawling, suggest that substantial supplies of phosphorus and other nutrients in sediment deposits frequently are resuspended to support algal growth.

Culture techniques. Culture isolates of Pfiesteria piscicida were collected on 23 May 1991 from the Pamlico River Estuary near Channel Marker no. 9 at the mouth of Blount Bay in Beaufort County, North Carolina, dur-

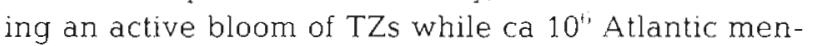
haden Brevoortia tyrannus Latrobe, southern flounder Paralichthys lethostigma Jordan \& Gilbert, hogchokers Trinectes maculatus Block \& Schneider and spot Leiostomus xanthuris Lacepede were dying (Burkholder et 
al. 1992, NC DEHNR 1992). Stock P. piscicida cultures were maintained in isolated, quarantined facilities under 25 to $50 \mu$ Ein $\mathrm{m}^{-2} \mathrm{~s}^{-1}$ (cool white fluorescent lamps) at 18 to $20^{\circ} \mathrm{C}$ with a $12: 12 \mathrm{~h}$ light:dark (L:D) cycle in $40 \mathrm{l}$ aerated, covered aquaria filled with artificial seawater at $15 \mathrm{ppt}$ salinity (standard medium; derived by adding Instant Ocean salts to deionized water). Contact with culture water and associated neurotoxic aerosols has been associated with serious human health effects (Glasgow et al. 1994, unpubl.). Hence, all work was completed using full-face respirators with organic acid filters; disposable gloves, boots and hair covers; and protective clothing that was bleached ( $\geq 30 \%$ solution) after use to kill all dinoflagellate stages.

pfiesteria piscicida requires an unidentified substance(s) in fresh fish excreta to initiate toxin production (Burkholder et al. 1992); hence, it was necessary to maintain toxic cultures using live fish. We routinely fed the dinoflagellate tilapia Oreochromica mossambica Peters (length 5 to $7 \mathrm{~cm}$, rinsed thoroughly with deionized water; source Lake Geneva Fisheries, Geneva, AL, USA) at a density of 9 to 12 fish $d^{-1}$, and removed all dead fish as live replacements were added. The tilapia selected as the standard test species is not endemic but, nonetheless, is susceptible to the dinoflagellate's toxin. It offered the advantages of constant availability, wide salinity tolerance, and certainty of no prior contamination by local $P$. piscicida populations. Stock tilapia were cultured in a separate building; to avoid contamination, fish cultures were not visited after personnel had been in the dinoflagellate facility without shower and complete change of clothing. Using these precautions, we successfully prevented dinoflagellate contamination of stock fish.

For all tests involving fish, each aquarium was filled with artificial seawater at 15 ppt salinity (except when testing salinity optima) that was continually filtered

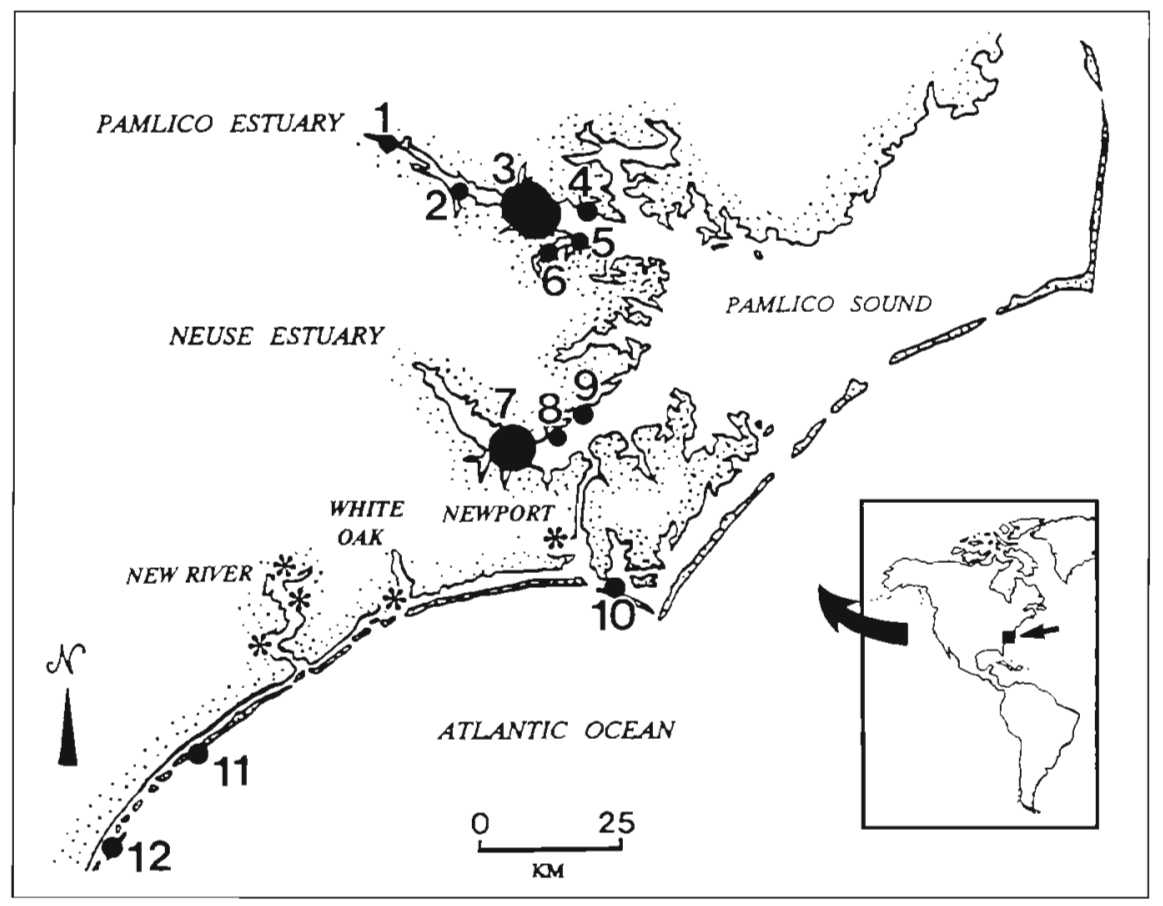

Fig. 1. Main study area (North Carolina, USA) showing the Neuse and Pamlico Estuaries and tributaries where toxic outbreaks of Pfiesteria piscicida have occurred (circles; large circles represent sites where fish kills were most frequent and affected a considerable area ). Sites: (1) below the city of Washington; (2) Hills Creek; (3) major 'hot spot' including Broad Creek, Blount CreekBlount Bay, Ragged Point, Tripp Point, Bath Creek, Core Point; (4) area of Bayview, Hawkins Beach; (5-6) South Creek (location of Texasgulf phosphorus mine); (7) Flanners Beach - Cherry Point - Minnesott Beach segment; (8) Dawson Creek; (9) Coffee Creek; (10) Taylor's Creek; (11) Topsail Beach; (12) Wrightsville Beach. Note that sites with highest activity were located about midway down the estuarine salinity gradient (mean salinity $12 \mathrm{ppt}$ ), a pattern that was corroborated by laboratory tests for $\mathrm{TZ}$ salinity optima (see text and Fig. 4). The largest blackened area, on the Pamlico, indicates the area with highest incidence of toxic outbreaks, whereas the large circle on the Neuse at Cherry Point - Minnesott Beach designates the site with highest known fish loss. The latter kill was unusual in that it was not short-term but, rather, occurred over a 6 wk period during autumn 1991 when schools of Atlantic menhaden were moving out to sea more than 1 billion fish were affected, and bulldozers were used to clear the shorelines. Also shown are locations (*) where amoebae and zoospores of $P$ piscicida have been found at densities $>300$ cells $\mathrm{ml}^{-1}$. Ulcerative fish diseases are common in the New River Estuary as well as the Pamlico, suggestive of sublethal toxic activity by this dinoflagellate 
and aerated. The light regime was set at a 12:12 h L:D cycle $\left(30 \mu \operatorname{Ein} \mathrm{m}^{-2} \mathrm{~s}^{-1}\right)$ except when testing light effects. Aquaria were maintained for $14 \mathrm{~d}$ before adding 3 tilapia to each. Fish were acclimated $7 \mathrm{~d}$ to ensure viability, and were fed daily with several flakes of Tetra Marin food unless otherwise indicated. The cultures also contained occasional small flagellates (e.g. Tetraselmis sp.), blue-green algae (Lyngbya sp. and Gloeothece spp.), and protozoan ciliates (Saprophilus sp., Microthorax sp., and Stylonichia putrina Dragesco \& Njine; Lee et al. 1985).

Bioassays to confirm toxic stages and response of fish species. In checking water samples for the presence of this toxic dinoflagellate in the Neuse and Pamlico (May 1991 to December 1993), other coastal areas (May 1992 to September 1993), and aquaculture facilities (January 1992 to May 1994), aquarium bioassays with fish were used to discern the small, nondescript $\mathrm{TZs}$ from other co-occurring, nontoxic estuarine dinoflagellates that are similar in appearance under light microscopy. In the aquarium bioassays, tilapia were exposed to field water samples under similar conditions as those used to maintain stock cultures. Toxicity, where present, was confirmed in $\leq 14 \mathrm{~d}$. We preserved samples with acidic Lugol's solution (Vollenweider 1974), and quantified abundance of toxic stages (TZs and planozygotes, diameter 10 to $60 \mu \mathrm{m}$ ) with an Olympus IMT-2 inverted microscope (phase, $600 \times)$ using the Utermöhl technique from Lund et al. (1958) in Burkholder \& Wetzel (1989). At least 400 cells were analyzed from each sample, with bioassays generally sampled at 1 to 2 d intervals. Stage identifications in water from fish kills, bioassays, and other field/aquaculture samples were confirmed using scanning electron microscopy (Burkholder et al. 1992). In April 1994, we also received samples from a coastal North Carolina aquaculture facility where juvenile clams Mercenaria mercenaria Linne were dying, and checked these samples for toxic dinoflagellate stages.

Each aquarium was covered with a tightly fitting polyethylene sleeve to minimize the potential for crosscontamination, except for short periods (min) when sampling, feeding fish, or exchanging dead with live fish. For all bioassays, controls consisted of fish maintained without dinoflagellate inocula (from cultured or field populations\}. Direct microscope counts of preserved samples collected at 1 to 2 d intervals indicated that controls did not become contaminated except during bioassays with blue crabs Callinectes sapidus Rathbun from local habitat.

Similar tests were also completed with other fish species to assess their susceptibility to the TZs. These bioassays were performed as single-species (finfish) trials, or as species with/without tilapia (shellfish). Representative shellfish included blue crabs; bay scallops
Argopecten irradians Lamarck; and eastern oysters Crassostrea virginica Gmelin which were assayed only without finfish. Triplicate aquaria with 2 to 15 finfish (depending on the species) in 91 of $15 \mathrm{ppt}$ Instant Ocean water were used for each species bioassay. The aquaria were each inoculated with active toxic culture to effect

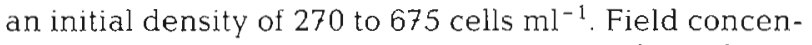
trations of active TZs typically range from $10^{2}$ to $10^{3}$ cells $\mathrm{ml}^{-1}$ (Burkholder et al. 1993). Behavior and survival of animals in these aquaria versus in triplicate controls without the dinoflagellate were compared for 2 to $4 \mathrm{wk}$ under standard culture conditions. Adults were tested in all cases except for bioassays with hybrid striped bass Morone saxatilis $\times$ Morone chrysops Rafinesque, [both juveniles (length ca $25 \mathrm{~cm}$ ) and adults / and oysters (pediveligers and adults; G. Krantz, Oxford Cooperative Laboratory, MD, USA, with J.M.B. and H.B.G.).

In the shellfish bioassays without finfish, bay scallops ( 3 per aquarium; shell width 4 to $5 \mathrm{~cm}$ ) and blue crabs (1 per aquarium; carapace width 8 to $10 \mathrm{~cm}$ ) were fed dilute concentrations of TZs for 9 to $14 \mathrm{~d}$. Blue crabs were also fed small tilapia and freeze-dried/rehydrated shrimp. Direct microscope counts of preserved samples collected at daily intervals were used to assess feeding activity as cell depletion. Oyster pediveliger larvae (ca 100 per replicate; $\mathrm{n}=3$ ) were examined for feeding and settling/attachment behavior when added to vessels containing cleaned autoclaved adult oyster shells with TZs (ca 1000 cells $\mathrm{ml}^{-1} \mathrm{~d}^{-1}$ for $2 \mathrm{~d}$ ), an equal biovolume of nontoxic Pseudoisochrysis sp. (Prymnesiophyceae), or mixed toxic/nontoxic prey (15 ppt salinity, $21^{\circ} \mathrm{C}, 30 \mu \operatorname{Ein} \mathrm{m}^{-2} \mathrm{~s}^{-1}, 12: 12 \mathrm{~h} \mathrm{~L}$ :D cycle, $24 \mathrm{~h}$ ). Direct microscope counts of preserved samples collected at $2 \mathrm{~h}$ intervals (first $12 \mathrm{~h}$ ) indicated that both pediveligers and adults consumed $\mathrm{TZs}_{\mathrm{s}}$ in the case of pediveligers, this feeding activity was corroborated with video imagery. Adult oysters were fed 3 times daily with TZs from active stock cultures to maintain available dinoflagellate food at 500 to $1000 \mathrm{cells} \mathrm{m}^{-1}$ or higher. Shellfish were considered dead if they ceased movement for $\geq 4$ h after the suspected time of death (pediveligers: no further motion or ciliary action; additionally for bay scallops, open gaping shells with no further change for $48 \mathrm{~h}$ ).

Distribution in the mid-Atlantic and southeastern United States. Toward determining the distribution of toxic ambush-predator dinoflagellates along the Atiantic and Gulf Coasts (1992 to 1994), water samples from known sites of sudden-death fish kills and ulcerative disease in nutrient-enriched areas of the Indian River Inland Bay, Delaware (supplied by B. Anderson \& R. Miller, Delaware Department of Natural Resources, fall 1992), Charleston, South Carolina (early spring 1993), the St. Johns River and Pensacola Bay, Florida (collected in summer 1993 by colleagues K. Steidinger 
and J. Landsberg of the Florida Department of Environmental Protection, Marine Research Institute, with J.M.B.), and Mobile Bay, Alabama (supplied by $\mathrm{H}$. Awetman, summer 1993) were also bioassayed with tilapia. Aquarium bioassays with tilapia were used by Lewitus et al. (1995) to test for the presence of Pfiesteria piscicida in Chesapeake Bay (Jenkins Creek, tributary to the Choptank River, summer 1993; stage identifications confirmed by J.M.B. \& H.B.G.). Preserved samples from nutrient-enriched locations in Flamingo Bay and the Indian River, Florida (summer 1994), and Benedict Laboratory, Solomons, Maryland (in the latter case, water from the Patuxent River added to fish aquaria, with subsequent fish death; sampled in spring 1994 by K. Sellner, D. Britburg and C. Pacey, with identifications confirmed by H.B.G. \& J.M.B.) were analyzed for flagellated and amoeboid stages of Pfiesteria-like species.

Optimum physical conditions for toxic activity. Under field and aquaculture conditions, toxic outbreaks of Pfiesteria piscicida occurred across a wide temperature gradient from 6 to $31^{\circ} \mathrm{C}$, with maximal toxic activity from TZs during the warm season (May through October). The most active toxic stage during colder periods was a large lobose a moeba (length ca 80 to $250 \mu \mathrm{m}$ ), with secondary involvement of TZs. In contrast to temperature, influences of salinity (e.g. during estuarine stratification) and light were not clear from field data; hence, the effects of these 2 variables on toxic behavior were experimentally examined. The salinity experiment was conducted for $16 \mathrm{~d}$ as batch cultures of dinoflagellates that were maintained under conditions similar to those for stock cultures. Artificial seawater was adjusted to impose treatment salinities of $0,5,10,15,25$ and 35 ppt by altering the quantity of Instant Ocean salts added to wellwater from a source at North Carolina State University that was low in divalent cations $\left(<4 \mathrm{mg} \mathrm{Ca}{ }^{2+}+\mathrm{Mg}^{2+} \mathrm{l}^{-1}\right)$. Each treatment was maintained in triplicate $10 \mathrm{l}$ aquaria that were randomly distributed on tables. The aquaria were aerated and filtered, with filters acclimated for $14 \mathrm{~d}$ before introducing 3 small tilapia. After $7 \mathrm{~d}$ with daily feeding of fish, the aquaria were each inoculated with $200 \mathrm{ml}$ of dinoflagellate culture containing approximately 60 cysts or amoebae $\mathrm{ml}^{-1}$ (initial density ca 2 cells $\mathrm{ml}^{-1}$ ) from stock aquaria of $P$. piscicida that had been without live fish for ca 1 mo. During the $16 \mathrm{~d}$ salinity experiment, fish in triplicate controls (without the dinoflagellate) and treatments were not fed, and expired fish were replaced within $8 \mathrm{~h}$ of death. One $50 \mathrm{ml}$ sample was taken from each aquarium at $2 \mathrm{~d}$ intervals, and was preserved for analysis by the Utermöhl technique.

Experiments to test for light optima of toxic Pfiesteria piscicida stages were conducted for $25 \mathrm{~d}$ as batch cul- tures. The illumination source consisted of $\mathrm{VHO}$ cool white fluorescent lamps (model F48T12/CW/VHO) that maintained a constant intensity of $350 \mu$ Ein $\mathrm{m}^{-2}$ $\mathrm{s}^{-1}$ at a $30 \mathrm{~cm}$ distance from the near side wall of each tank. Covered culture aquaria were wrapped with neutral-density fiberglass screening to achieve 5 light treatments in triplicate (intensities of $0.2,25,50,75$, and $200 \mu$ Ein $\mathrm{m}^{-2} \mathrm{~s}^{-1}$, and then were placed on shelves with treatments randomly assigned by shelf row. The selected irradiances were within the range encountered by phytoplankton in moderately turbid estuarine waters such as the Neuse and Pamlico (Mallin \& Paerl 1992). Photosynthetically active radiation (PAR) was quantified using a LiCor data logger (model 1000) connected to a submersible $4 \pi$ PAR quantum sensor (model LI-193SA). Replicated controls (containing fish without $P$. piscicida in each light regime) were also positioned at randomly assigned locations on the shelves. After setup, each aquarium was inoculated with $200 \mathrm{ml}$ of dinoflagellate stock culture containing ca $300 \mathrm{TZs} \mathrm{ml}^{-1}$ (initial density ca 8 cells $\mathrm{ml}^{-1}$ ). Aquana were monitored twice daily to exchange dead with live fish and to add fish food, exposing each aquarium to an additional 8 to $9 \mu$ Ein $\mathrm{m}^{-2} \mathrm{~s}^{-1}$ (i.e. minimal background PAR) for 30 to $60 \mathrm{~s}$ during each exchange. One $50 \mathrm{ml}$ sample was taken (in the same 30 to $60 \mathrm{~s}$ period) at $5 \mathrm{~d}$ intervals, and was preserved for quantifying dinoflagellate stages.

In the salinity and light experiments, triplicate aquaria were also maintained with dinoflagellates (no fish; 'dinoflagellate-alone' control) to characterize the population structure at each salinity or light level. As expected, subsamples collected throughout the duration of each experiment revealed negligible or low densities (generally $<50$ cells $\mathrm{ml}^{-1}$ ) of flagellated and amoeboid stages in the water column of these systems without fish, nutrients, or abundant algal/microfauna prey (note: benthic areas were not sampled). Hence, the dinoflagellatealone controls were not considered further.

To statistically analyze the experimental data, correlation analyses were performed initially by date to examine relationships between the abundance of various stages of Pfiesteria piscicida with salinity or light. After testing for homogeneity of variance (Hartley's test; Gill 1978), data were square-root transformed where appropriate (SAS Institute, Inc. 1987). One-way ANOVAs were used to detect differences among treatments in abundances of TZs, gametes, planozygotes, cysts and amoebae. Treatment means were compared using Fisher's protected least significant difference test, with a comparisonwise error rate $(\alpha=0.05$; SAS Institute, Inc. 1987, Day \& Quinn 1989). Repeated-measures analysis was used to test for differences among treatments over time in abundances of life cycle stages (SAS Institute, Inc. 1987, Potvin \& Lechowicz 1990). 
Table 1. Estuarine/coastal fish kills linked to the presence of flagellated stages (flag.) of Pfiesteria piscicida through sample identification with confirming scanning electron micrographs and bioassays for fish toxicity. na: not available

\begin{tabular}{|c|c|c|c|c|c|c|c|}
\hline Month & Location & $\begin{array}{l}\text { Salinity } \\
\text { (ppt) }\end{array}$ & $\begin{array}{l}\text { Temp. } \\
\left({ }^{\circ} \mathrm{C}\right)\end{array}$ & \multicolumn{2}{|c|}{$\begin{array}{l}\text { Nutrients } \\
\left.(\mu g]^{-1}\right)\end{array}$} & $\begin{array}{l}\text { P. piscicida } \\
\left.\text { (flag. } \mathrm{ml}^{-1}\right)^{a}\end{array}$ & $\begin{array}{l}\text { Affected taxa, number } \\
\text { affected, notes }\end{array}$ \\
\hline $\begin{array}{l}1991 \\
\text { May }\end{array}$ & $\begin{array}{l}\text { Pamlico: Blount Bay, } \\
\text { Core Point, Bath Creek }\end{array}$ & $4-6$ & $24-26$ & $\begin{array}{l}\text { TP } \\
\mathrm{PO}_{4}^{3-}-\mathrm{P} \\
\mathrm{TKN}^{3} \\
\mathrm{NH}_{4}{ }^{+}-\mathrm{N}\end{array}$ & $\begin{array}{l}130-240 \\
70 \\
500-600 \\
10-20\end{array}$ & 750 & $\begin{array}{l}\text { Atlantic menhaden, southern } \\
\text { flounder, spot, hogchoker } \\
(1000000)\end{array}$ \\
\hline June & Pamlico: Tripp Point ${ }^{\mathrm{b}}$ & 4 & 29 & $\begin{array}{l}\mathrm{TP} \\
\mathrm{PO}_{4}^{3-}-\mathrm{P} \\
\mathrm{TKN}^{3} \\
\mathrm{NO}_{3}{ }^{-}-\mathrm{N} \\
\mathrm{NH}_{4}^{+}-\mathrm{N}\end{array}$ & $\begin{array}{c}130-140 \\
40-50 \\
500-600 \\
<10 \\
10\end{array}$ & 1050 & $\begin{array}{l}\text { Atlantic menhaden, } \\
\text { others }(15000)\end{array}$ \\
\hline Aug & $\begin{array}{l}\text { Pamlico: Washington } \\
\text { (near WWTP) }^{\mathrm{c}}\end{array}$ & 8 & 28 & $\begin{array}{l}\mathrm{TP} \\
\mathrm{TKN} \\
\mathrm{NO}_{3}^{-}-\mathrm{N} \\
\mathrm{NH}_{4}^{+}-\mathrm{N}\end{array}$ & $\begin{array}{r}500 \\
700 \\
<10 \\
70\end{array}$ & $>7400$ & Atlantic menhaden $(>1000)$ \\
\hline Aug & Pamlico: Hawkins Beach & 12 & 29 & $\begin{array}{l}\mathrm{TP} \\
\mathrm{TKN} \\
\mathrm{NO}_{3}^{-}-\mathrm{N} \\
\mathrm{NH}_{4}^{+}-\mathrm{N}\end{array}$ & $\begin{array}{r}490 \\
700 \\
<10 \\
40\end{array}$ & 26050 & $\begin{array}{l}\text { Southern flounder } \\
\text { 'walk' }(1000)\end{array}$ \\
\hline Sep & Neuse: Dawson Creek & $7-8$ & 30 & $\begin{array}{l}\mathrm{TP} \\
\mathrm{PO}_{4}{ }^{3-}-\mathrm{P} \\
\mathrm{TKN}^{-} \\
\mathrm{NO}_{3}{ }^{-}-\mathrm{N} \\
\mathrm{NH}_{4}{ }^{+} \mathrm{N}\end{array}$ & $\begin{array}{l}120 \\
70 \\
500-600 \\
<10 \\
20\end{array}$ & 350 & $\begin{array}{l}\text { White perch, catfish, } \\
\text { striped mullet } \\
\text { (number na) }\end{array}$ \\
\hline Sep & Pamlico: near Hills Creek & 4 & 27 & $\begin{array}{l}\mathrm{TP} \\
\mathrm{TKN} \\
\mathrm{NO}_{3}^{-}-\mathrm{N} \\
\mathrm{NH}_{4}{ }^{+}-\mathrm{N}\end{array}$ & $\begin{array}{l}420 \\
700-800 \\
<10 \\
30\end{array}$ & 520 & $\begin{array}{l}\text { Spot, American eel, } \\
\text { others }(2000)\end{array}$ \\
\hline Sep-Oct & $\begin{array}{l}\text { Neuse: Minnesott Beach, } \\
\text { Cherry Point (near } \\
\text { WWTP) }\end{array}$ & $7-10$ & $18-30$ & $\begin{array}{l}\mathrm{TP} \\
\mathrm{PO}_{4}^{3-}-\mathrm{P} \\
\mathrm{TKN} \\
\mathrm{NO}_{3}{ }^{-}-\mathrm{N} \\
\mathrm{NH}_{4}{ }^{4}-\mathrm{N}\end{array}$ & $\begin{array}{l}120-150 \\
70 \\
500-600 \\
<10 \\
20\end{array}$ & $520-1120$ & $\begin{array}{l}\text { Atlantic menhaden, blue } \\
\text { crab 'walks' ( }-1 \text { billion) }\end{array}$ \\
\hline Dec & $\begin{array}{l}\text { Taylors Creek } \\
\text { (near WWTP) }^{c}\end{array}$ & 30 & 15 & na & & 35360 & $\begin{array}{l}\text { Fish 'walk': southern } \\
\text { flounder, American eel, } \\
\text { sheepshead, others ( } 2000)\end{array}$ \\
\hline Dec & $\begin{array}{l}\text { Atlantic, ca } 5 \mathrm{~km} \text { from } \\
\text { shore at Wrightsville Beach }\end{array}$ & 35 & 17 & na & & $50^{b}$ & Atlantic menhaden $(>5000)$ \\
\hline $\begin{array}{l}1992 \\
\text { Jul }\end{array}$ & $\begin{array}{l}\text { Pamlico: Bayview } \\
\text { (near WWTP) }^{c}\end{array}$ & 7 & 29 & $\begin{array}{l}\mathrm{TP} \\
\mathrm{PO}_{4}{ }^{3-}-\mathrm{P} \\
\mathrm{TKN}^{-} \\
\mathrm{NO}_{3}{ }^{-}-\mathrm{N} \\
\mathrm{NH}_{4}{ }^{+}-\mathrm{N}\end{array}$ & $\begin{array}{r}150-210 \\
80-100 \\
400-500 \\
40 \\
<10\end{array}$ & 350 & Atlantic menhaden $(100-500)$ \\
\hline Jul & Pamlico: Hawkins Beach & 8 & 29 & $\begin{array}{l}\mathrm{TP} \\
\mathrm{TKN} \\
\mathrm{NO}_{3}^{-}-\mathrm{N} \\
\mathrm{NH}_{4}^{+}-\mathrm{N}\end{array}$ & $\begin{array}{r}370 \\
800 \\
<10 \\
80\end{array}$ & 910 & $\begin{array}{l}\text { Atlantic menhaden, Atlantic } \\
\text { croaker }(1000-2000)\end{array}$ \\
\hline $\mathrm{Jul}$ & Pamlico: Ragged Point & 7 & 30 & $\begin{array}{l}\mathrm{TP} \\
\mathrm{TKN} \\
\mathrm{NO}_{3}^{-}-\mathrm{N} \\
\mathrm{NH}_{4}^{+}-\mathrm{N}\end{array}$ & $\begin{array}{l}220 \\
500 \\
<10 \\
100\end{array}$ & 3310 & $\begin{array}{l}\text { Atlantic menhaden, } \\
\text { Atlantic croaker }(>100000)\end{array}$ \\
\hline Jul & $\begin{array}{l}\text { Pamlico: South Creek } \\
\text { (near P mining) }^{c}\end{array}$ & 8 & 30 & $\begin{array}{l}\mathrm{TP} \\
\mathrm{TKN} \\
\mathrm{NO}_{3}^{-}-\mathrm{N} \\
\mathrm{NH}_{4}^{-}-\mathrm{N}\end{array}$ & $\begin{array}{r}200 \\
400 \\
<10 \\
10\end{array}$ & 2410 & $\begin{array}{l}\text { Atlantic menhaden } \\
\text { (thousands with lesions) }\end{array}$ \\
\hline Jul & $\begin{array}{l}\text { Neuse: Minnesott } \\
\text { Beach, Cherry Point } \\
\text { (near WWTP) }^{c}\end{array}$ & 9 & 26 & $\begin{array}{l}\mathrm{TP} \\
\mathrm{TKN} \\
\mathrm{PO}_{4}^{3-}-\mathrm{P} \\
\mathrm{NO}_{3}{ }^{-}-\mathrm{N} \\
\mathrm{NH}_{4}{ }^{+}-\mathrm{N}\end{array}$ & $\begin{array}{r}150 \\
400 \\
100 \\
10 \\
10\end{array}$ & 630 & $\begin{array}{l}\text { Atlantic menhaden, } \\
\text { others }(1000-5000)\end{array}$ \\
\hline
\end{tabular}


Table 1 (continued)

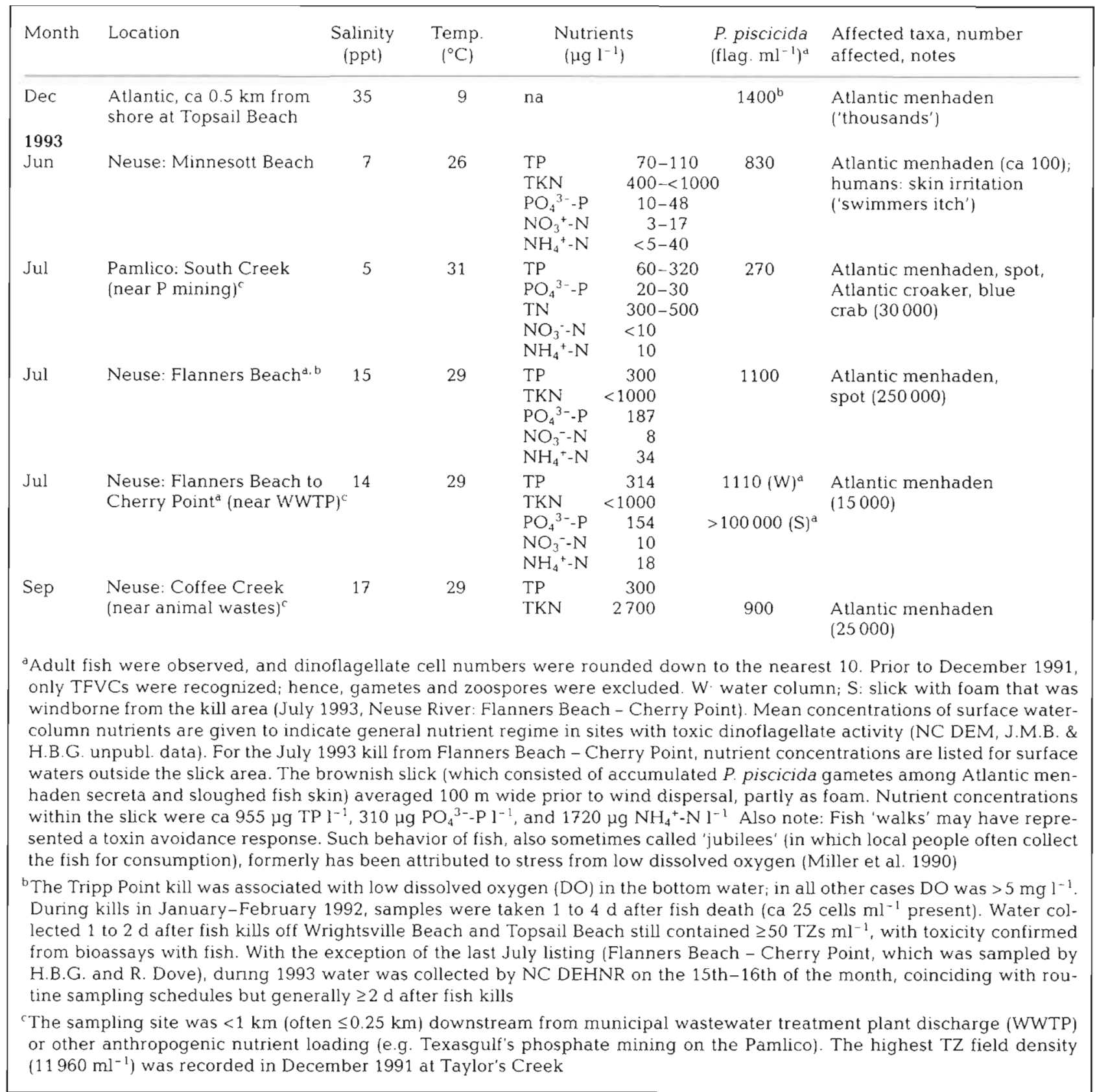

\section{RESULTS}

\section{Distribution and toxic outbreaks of ambush- predator dinoflagellates}

Water samples were collected from 27 field fish kills and 9 aquaculture kills (Tables 1 \& 2). An additional aquaculture kill was sampled by $\mathrm{P}$. Tester [National Marine Fisheries Service (NMFS), Beaufort, NC] and colleagues, and the water was found to contain the dinoflagellate at sublethal concentrations 1 to $3 \mathrm{~d}$ after fish had died (P. Tester unpubl. data). In about twothirds of the fish kills, samples were taken while the 'sudden-death' kills (usually $<48 \mathrm{~h}$ in duration, and frequently much shorter) were in progress, and $\mathrm{TZ}$ densities were $\geq 250$ cells $\mathrm{ml}^{-1}$. In the remaining kills, samples were collected 2 to $4 \mathrm{~d}$ after fish death, when the presence of common filose and lobose amoebae suggested that dinoflagellate transformations from toxic flagellated stages had already occurred.

Toxic outbreaks of Pfiesteria piscicida in local estuaries occurred at mean temperature and salinity of $26 \pm$ 
$2^{\circ} \mathrm{C}$ and $12 \pm 2$ ppt [mean \pm 1 standard error $(\mathrm{SE}) ; \mathrm{n}=$ 17 dates; authors' data in combination with $\mathrm{NC}$ DEHNR 1992 and NC DEHNR unpubl. records; Table 1], indicating that this dinoflagellate is predominantly an estuarine, warm-temperate species. Lethal stages were most active in nutrient-rich waters (status inferred using information from Rudek et al. 1991, Jaworski et al. 1992, Dennison et al. 1993, Mallin 1994), with mean total phosphorus (TP), ammonium, and total nitrogen (TN) or total Kjeldahl nitrogen (TKN) at $275 \pm 30 \mu \mathrm{g} \mathrm{TP}{ }^{-1}(\mathrm{n}=16), 35 \pm 10 \mu \mathrm{g} \mathrm{NH}_{4} \pm$ $\mathrm{Nl}^{-1}(\mathrm{n}=13)$, and $810 \pm 135 \mu \mathrm{g} \mathrm{TN}$ or TKN ${ }^{-1}(\mathrm{n}=16)$, respectively (data supplemented by NC DEHNR 1992 and NC DEHNR unpubl. records; Table 1).

We obtained fresh (unpreserved) samples from 28 of the 36 field and aquaculture kills after 1 to $2 \mathrm{~d}$, and confirmed toxic activity of the dinoflagellate from laboratory bioassays in all of 26 samples tested; the remaining 2 kills were sampled from aquaculture facilities during 1994, when laboratory redesign for improved safety precautions prevented completion of confirming bioassays for toxic activity. To conservatively estimate the role of this toxic dinoflagellate in major fish kills from North Carolina's estuaries, we discounted other field kills in which Pfiesteria piscicida was present but more than one-third of the water column had low dissolved oxygen $\left(\leq 4 \mathrm{mg} \mathrm{l}^{-1}\right)$. In contrast, 8 field kills (although with delayed sampling of $\geq 4$ d) yielded no evidence of $P$. piscicida stages in fresh or preserved material, nor in subsequent bioassays of live samples with tilapia, and hence were considered 'negative' tests. The majority of those kills were associated with anoxia or hypoxia (usually $\leq 3 \mathrm{mg} \mathrm{l}^{-1}$ ) in the lower water column (NC DEHNR 1992, unpubl. records).

During Year 1 (May to December 1991) in estuaries and coastal waters, 8 of 15 major fish kills (defined as affecting $\geq 10^{3}$ fish) were linked to Pfiesteria piscicida (Table 1, in combination with data from NC DEHNR 1992 and NC DEHNR unpubl. fish kill records). In contrast to the relatively warm conditions from spring to fall 1991 (with water temperatures at 28 to $30^{\circ} \mathrm{C}$ by late May; NOAA 1992a), the summer of 1992 was the third coldest in a $50 \mathrm{yr}$ record (NOAA 1993), and yielded fewer field kills but more numerous aquaculture kills relative to the previous year (Tables $1 \& 2$; but note: field and aquaculture fish kills prior to May 1991 were not sampled and, thus, could not be considered). The dinoflagellate's TZs were implicated in 5 of 8 major field kills during Year 2 (data considered in combination with fish kill records from NC DEHNR unpubl. records; Fig. 2A, B). In Year 3 (1993), P. piscicida was found in lethal densities, with toxicity subsequently confirmed from laboratory bioassays, at 4 of 10 major fish kills (Table 1, considered with NC DEHNR unpubl. fish kill records; but note: samples from only those
5 kills were available for analysis). Hence, our field data and supporting laboratory bioassays implicated $P$. piscicida as the causative agent of $52 \pm 7 \%$ of the major fish kills annually in the North Carolina estuaries and coastal waters examined from 1991 to 1993. During all 3 years, open bleeding lesions were common on moribund and dead fish observed at the kills (Fig. 2E). Further, in these locations between kills, sublethal densities of $P$. piscicida flagellated and amoeboid stages often were found in surface waters (Fig. 2A to D), coinciding with ulcerations that were observed among fish species taken from pound nets by commercial fishermen.

Aside from these field kill sites, analysis of water samples collected in North Carolina estuaries between July and October 1993 confirmed the toxic dinoflagellate's presence in the South River downstream from Open Grounds Farm (with accompanying bioassays that confirmed toxicity), the Newport River, the White Oak River near Swansboro, the New River (Northeast Creek, Stones Bay, Hadnot Point, Wallace Creek, Courthouse Bay and Sneads Ferry Marina), and the Cape Fear River (ca $100 \mathrm{~m}$ from the Wilmington municipal wastewater treatment plant). Finfish and shellfish kills associated with TZs or, more frequently, with large lobose amoebae (Fig. 2C), also occurred in aquaculture facilities, especially within indoor tanks during winter-spring, a short time (days) after incoming estuarine water was warmed to $>20^{\circ} \mathrm{C}$ (Table 2).

Fish culture bioassays of water or surficial sediment samples collected from selected, known sudden-death fish kill sites in eutrophic estuaries of Delaware, Maryland (Jenkins Creek, Chesapeake Bay; bioassay data of Lewitus et al. 1995), South Carolina, Florida, and Alabama confirmed the presence of the dinoflagellate's TZs (Fig. 3). Outbreaks of Pfiesteria piscicida TZs occurred in all cultures except those from Pensacola Bay and Mobile Bay, A second Pfiesteria-like species (Landsberg et al. 1995) was found in preserved samples and in fish bioassays of fresh samples from the St. Johns River, the Indian River, Flamingo Bay, Pensacola Bay, and Mobile Bay (Fig. 3). P. piscicida was found in preserved samples from a site on the York River, Virginia; and another site in the Chesapeake, the Patuxent River, apparently provided an inoculum of the $P$. piscicida population that was implicated in an adjacent aquaculture kill (Table 2).

\section{Affected species of finfish and shellfish}

The TZs of Pfiesteria piscicida were lethal to all fish observed during kills in estuarine habitat or aquarium

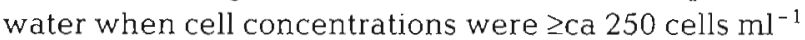
(Tables $1 \& 2$ ), which is also the approximate density at 
Table 2. Summary of aquaculture finfish and shellfish kills linked to the presence of Pfiesteria piscicida through sample identification, confirming scanning electron micrographs, and bioassays for fish toxicity. ${ }^{a}$ NMFS: National Marine Fisheries Service; na: not available

\begin{tabular}{|c|c|c|c|c|c|}
\hline Month & Location $^{\alpha}$ & $\begin{array}{l}\text { Salinity } \\
\text { (ppt) }\end{array}$ & $\begin{array}{l}\text { Temp. } \\
\left({ }^{\circ} \mathrm{C}\right)\end{array}$ & $\begin{array}{l}\text { P. piscicida } \\
\left.\text { (cells } \mathrm{ml}^{-1}\right)\end{array}$ & $\begin{array}{l}\text { Affected taxa }{ }^{\mathrm{d}} \text {, number } \\
\text { affected, notes }\end{array}$ \\
\hline \multicolumn{6}{|l|}{1992} \\
\hline Jan & $\begin{array}{l}\text { Aquaculture (Pamlico; } \\
\text { Castle Hayne Aquifer) }\end{array}$ & 0 & 6 & $n a^{a, b}$ & $\begin{array}{l}\text { Hybrid striped bass ( } 25000 \\
\$ 90000 \text { loss); with lesions }\end{array}$ \\
\hline Feb & $\begin{array}{l}\text { NC Maritime Museum, } \\
\text { Beaufort (Newport River) }\end{array}$ & 27 & 21 & $n a^{a, b}$ & $\begin{array}{l}\text { Sheepshead, others } \\
\text { (number na); with lesions }\end{array}$ \\
\hline Feb & $\begin{array}{l}\text { NMFS, Beaufort } \\
\text { (Taylor's Creek) }\end{array}$ & 24 & 19 & $\begin{array}{l}120 \text { TZs, } \\
80 \text { gametes, } \\
40 \text { amoebae }\end{array}$ & $\begin{array}{l}\text { Atlantic menhaden (ca 20); } \\
\text { with lesions }\end{array}$ \\
\hline Mar & $\begin{array}{l}\text { NMFS, Beaufort } \\
\text { (Taylor's Creek) }\end{array}$ & 28 & 20 & $\begin{array}{l}60 \mathrm{TZs}, \\
80 \text { gametes, } \\
30 \text { amoebae }^{b}\end{array}$ & $\begin{array}{l}\text { Atlantic menhaden } \\
(>2000 \text { larvae) }\end{array}$ \\
\hline Nov & $\begin{array}{l}\text { NMFS, Beaufort } \\
\text { (Taylor's Creek) }\end{array}$ & 25 & 14 & $\begin{array}{l}180 \text { TZs, } \\
80 \text { gametes, } \\
10 \text { amoebae }\end{array}$ & $\begin{array}{l}\text { Southern flounder } \\
(14)_{i} \text { with lesions }\end{array}$ \\
\hline Jan & $\begin{array}{l}\text { Dept of Zoology, NCSU } \\
\text { (Neuse) }\end{array}$ & 15 & 20 & $\begin{array}{l}1260 \text { TZs, } \\
1800 \text { gametes, } \\
40 \text { amoebae }\end{array}$ & $\begin{array}{l}\text { Tilapia, white perch } \\
\text { (ca 30); with lesions }{ }^{c}\end{array}$ \\
\hline May & $\begin{array}{l}\text { Dept of Zoology, NCSU } \\
\text { (Charleston, SC) }\end{array}$ & 15 & 20 & $\begin{array}{l}2700 \text { TZs, } \\
240 \text { gametes, } \\
560 \text { amoebae }\end{array}$ & $\begin{array}{l}\text { Tilapia (75); } \\
\text { with lesions }^{c}\end{array}$ \\
\hline \multicolumn{6}{|l|}{1994} \\
\hline Feb-Mar & $\begin{array}{l}\text { Benedict, MD (Patuxent River, } \\
\text { Chesapeake Bay) }\end{array}$ & 9 & 22 & $\begin{array}{l}1070 \mathrm{TZs}, \\
1870 \text { gametes, } \\
620 \text { amoebae }\end{array}$ & $\begin{array}{l}\text { Naked goby }(64)_{i} \\
\text { with lesions }{ }^{\text {a,c }}\end{array}$ \\
\hline Apr & $\begin{array}{l}\text { NMFS, Beaufort } \\
\text { (Taylor's Creek) }\end{array}$ & 36 & 20 & $n a^{a, b}$ & $\begin{array}{l}\text { Atlantic menhaden }(20 \\
\text { pathology consistent with } \\
\text { toxin effects })^{\text {d }}\end{array}$ \\
\hline May-Jun & $\begin{array}{l}\text { Vicinity of Camp } \\
\text { Lejeune (White Oak River) }\end{array}$ & 28 & 24 & $\begin{array}{l}980 \text { TZs, } \\
5700 \text { gametes, } \\
780 \text { amoebae }\end{array}$ & $\begin{array}{l}\text { Littleneck clam (8000 } \\
\text { larvae; } \$ 20000 \text { loss })^{d}\end{array}$ \\
\hline \multicolumn{6}{|c|}{$\begin{array}{l}\text { aLocations include the water source used in the facility. Dinoflagellate densities were rounded down to the nearest } 10 ; \\
\text { affected fish were adults unless otherwise indicated. Descriptions of facilities and fish involved during February-March } 1994 \\
\text { were provided by } \mathrm{D} \text {. Britburg, C. Pacey \& K. Sellner from Benedict Estuarine Research Laboratory. The April } 1994 \mathrm{kill} \text { was } \\
\text { sampled } 1 \text { to } 3 \mathrm{~d} \text { after fish had died, and flagellated cells were reported at } \leq 170 \mathrm{ml}^{-1} \text { (P. Tester et al. unpubl. data) }\end{array}$} \\
\hline \multicolumn{6}{|c|}{$\begin{array}{l}\text { 'A delay of } 2 \text { to } 4 \text { d occurred between sampling and adding preservative, or between the time of the fish kill and sampling. In } \\
\text { the January } 1992 \text { 'sudden death' kill, hybrid striped bass died within } 4 \mathrm{~h}_{\text {; }} \text { prior to death they exhibited symptoms that were } \\
\text { consistent with those known to be induced by toxic } P \text {. piscicida. Bioassays of tilapia with field sample tested positive for toxic } \\
\text { activity by the dinoflagellate }\end{array}$} \\
\hline \multicolumn{6}{|c|}{$\begin{array}{l}\text { 'Fish apparently carried P. piscicida into the facilities from the Neuse Estuary (January 1993) or from waters near Charleston, } \\
\text { SC (May 1993) }\end{array}$} \\
\hline \multicolumn{6}{|c|}{$\begin{array}{l}{ }^{\mathrm{d}} \text { Confirming bioassays could not be completed because our laboratory was being renovated to ensure safety when working } \\
\text { with } P \text {. piscicida. Examination of the aquaculture facilities revealed that, despite passage of estuarine water through a series } \\
\text { of diatomaceous earth filters, small stages of the dinoflagellate had remained in the filtrate used to grow large cultures of } \\
\text { Isochrysis galbana Green (Prymnesiophyceae) that were maintained as a food supply for the clam larvae. These stock algal } \\
\text { cultures were found to contain numerous zoospores of } P \text {. piscicida that were thriving on } I \text {. galbana; thus, the unfortunate } \\
\text { aquaculturist had been feeding his clams a robust population of } P \text {. piscicida mixed with smaller nontoxic algae }\end{array}$} \\
\hline
\end{tabular}

which marine red tide dinoflagellates such as Gymnodinium breve Davis can be lethal to fish (Tester et al. 1991). The typical response followed this sequence: Upon initial exposure to water with high TZ activity, the fish quickly darkened in color (initial pale brown changing to dark brown/black mottling), became lethargic, and settled on the bottom of the aquarium. In increasingly frequent episodes, the fish suddenly struggled to the water surface and gulped air, but was not able to hold its position and slowly sank back down where it landed on its side, head or tail and, having lost its ability to maintain balance, leaned against the aquarium wall. The behavior appeared somewhat analogous to fish 'walks' reported by NC DMF biologists 

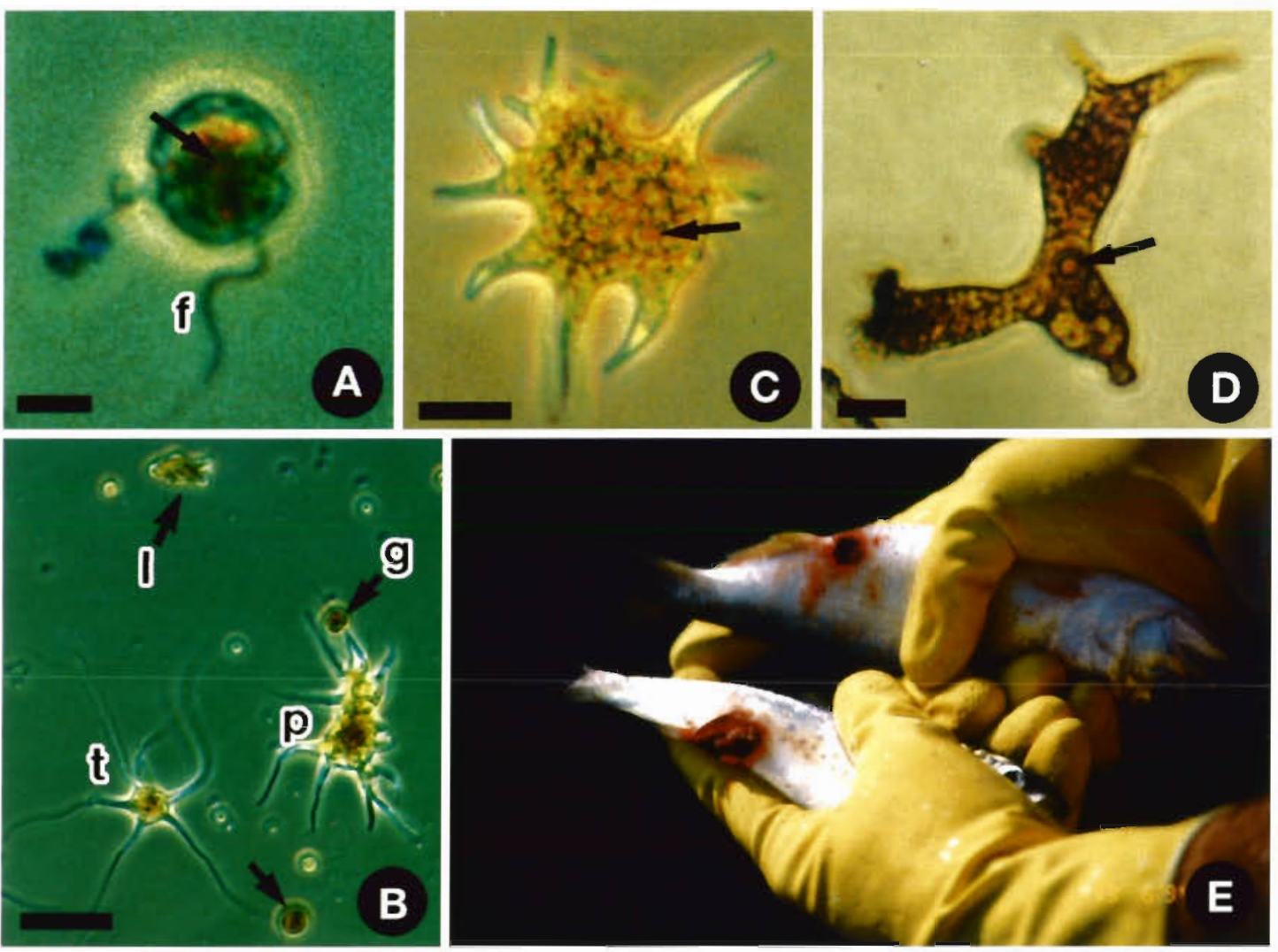

Fig. 2. Pfiesteria piscicida (acidic Lugol's-preserved) and appearance of sublethal toxin effects on fish. (A) Highly magnified darkly stained TZ with reddish nucleus (arrow) and prominent longitudinal flagellum (f); scale bar $=5 \mu m_{i}$ compare with scale of (B), the magnification of the original micrograph. (B) Appearance of a water sample from a recent aquarium fish kill showing a darkly stained TZ (arrow), a '-' anisogamous gamete $(\mathrm{g})$, filose amoebae from a TZ (t) and a planozgyote (p), and a small lobose amoeba likely transformed from a TZ (l); scale bar $=30 \mu \mathrm{m}$. (C) A larger lobose amoeba (colorless to light brown when alive), showing a reddish-stained nucleus (arrow) and tapering lobopodia with refractive appearance; scale bar $=25 \mu \mathrm{m}$. (D) A lobose amoeba of different shape and size, with prominent reddish nucleus (arrow); scale bar $=25 \mu \mathrm{m}$. (E) Moribund Atlantic menhaden with open bleeding ulcerations, collected while still swimming at the water surface (among ca $2 \times 10^{3}$ flagellated and amoeboid cells $\mathrm{ml}^{-1}$ of $P$. piscicida) in the Pamlico Estuary near Bath Creek (site 3 in Fig. 1). This area is noted for seasonally high abundance of $P$. piscicida, and high incidence of fish kills/disease; $98 \%$ of the fish sampled on that date in mid-June, among all species present, were similarly affected

during dinoflagellate- and hypoxia-related kills in natural habitat, wherein affected finfish as well as blue crabs attempt to move from the water to drier shorelines (Table 1). Lesions with sloughing of flecks or patches of epidermal tissue, and/or subcutaneous hemorrhaging developed as the exposure period lengthened and the fish began to expire. This bleeding was most noticeable for hybrid striped bass in the lymphatic canal beneath the dorsal fin, and for southern flounder in sores that formed on the ventral surface by the mouth. Many of the tested fish attempted to reach the well-aerated area by the aquarium filter and, if successful, remained there until death.

Among 19 finfish species bioassayed with Pfiesteria piscicida, all were killed in $<4 \mathrm{~d}$, and 13 additional species were involved in field or aquaculture kills linked to the dinoflagellate (Table 3). The lethal ichthyotoxic agent is unidentified neurotoxin(s) that is actively released as exotoxin(s) when the dinoflagellate's TZs, planozygotes, and lobose amoebae are stimulated by substance(s) in fresh fish secreta (Burkholder et al. 1992). When we exposed fish to water with aging dinoflagellate cysts (dormant $>2 \mathrm{yr}$ ), lethal effects often required about 6 to $8 \mathrm{wk}$. Cysts that had been inactive for 1 to 2 mo induced fish death in $\leq 14 \mathrm{~d}$. Recently formed cysts from highly active toxic populations, however, were capable of producing TZs that killed fish in hours, and TZs which had been given live fish repeatedly for days to weeks killed fish in minutes. Cultures that were maintained to provide high levels of toxin for biochemical characterization required 15 to 20 or more fish daily. In replicated bioassays with exotic fish species (>280 TZs ml ${ }^{-1}$; Table 3 ), hybrid striped bass were most susceptible (hemorrhaging and 
death of juveniles within minutes) whereas adult guppies and mosquitofish generally survived several days. Moreover, within a given species, susceptibility to the toxin(s) varied so that occasionally, some fish remained alive for hours or days after all other exposed fish had died. Subsequent addition of other live fish to the culture, however, consistently led to death of the formerly resistant individuals.

Bioassays with shellfish yielded similar results although blue crabs, bay scallops, and eastern oysters apparently did not strongly stimulate toxic activity. Blue crabs and scallops remained viable for 9 to $14 \mathrm{~d}$ test periods while filtering low concentrations of TZs (ca 60 cells $\mathrm{ml}^{-1}$ ), although perceptible loss of the scallop closing reflex indicated a narcotizing effect of the toxin(s). When placed into aquaria with dying finfish ( $\mathrm{TZ}$ densities $\geq 2100$ cells $\mathrm{ml}^{-1}$; active cultures given 8 tilapia $\mathrm{d}^{-1}$ ), however, blue crabs were killed within hours to several days after numerous frenzied attempts to leave the water. Efforts to maintain 4 of 6 blue crabs as controls failed, despite the fact that control tanks with crabs were each surrounded by control aquaria with unaffected tilapia (which consistently have tested more sensitive to Pfiesteria piscicida than blue crabs), as an added precaution against contamination by dinoflagellate cultures. These crabs had been collected from the Newport River, and were suspected to have carried small populations of encysted or amoeboid $P$. piscicida on their carapaces.

In an analogous pattern, within 2 min of exposure to TZ cultures with dying finfish, scallops exhibited an escape response (rapid propulsion backward until contacting the aquarium walls) and then closed their shells tightly. The shells gaped open and death ensued within $\leq 10$ min (indicated as no further change for $24 \mathrm{~h}$ ). Oyster pediveliger larvae were narcotized after consuming TZs for $\geq 2$ to $3 \mathrm{~h}$, indicated by depressed ciliary activity, premature settling behavior, and failure to attach to cleaned adult shells (Krantz et al. 1994). Approximately $50 \%$ of the tested pediveligers appeared moribund after $8 \mathrm{~h}$ of toxic exposure, and most died after 24 to $48 \mathrm{~h}$ with TZs. Adult oysters were also narcotized as evidenced by a slower closing reflex (Krantz et al. 1994), but continued to consume high concentrations of TZs over a $14 \mathrm{~d}$ test period (unpubl. data of J.M.B. \& H.B.G. with G. Krantz; however, note that neither oyster pediveligers nor adults were tested in the presence of dying finfish).

\section{Response to salinity and light gradients}

Over a $16 \mathrm{~d}$ test period, Pfiesteria piscicida TZs did not emerge from cysts that were placed in ca 0 ppt salinity from the low alkalinity water source, although
PFIESTERIA

KNOWN DISTRIBUTION (1991-1994)

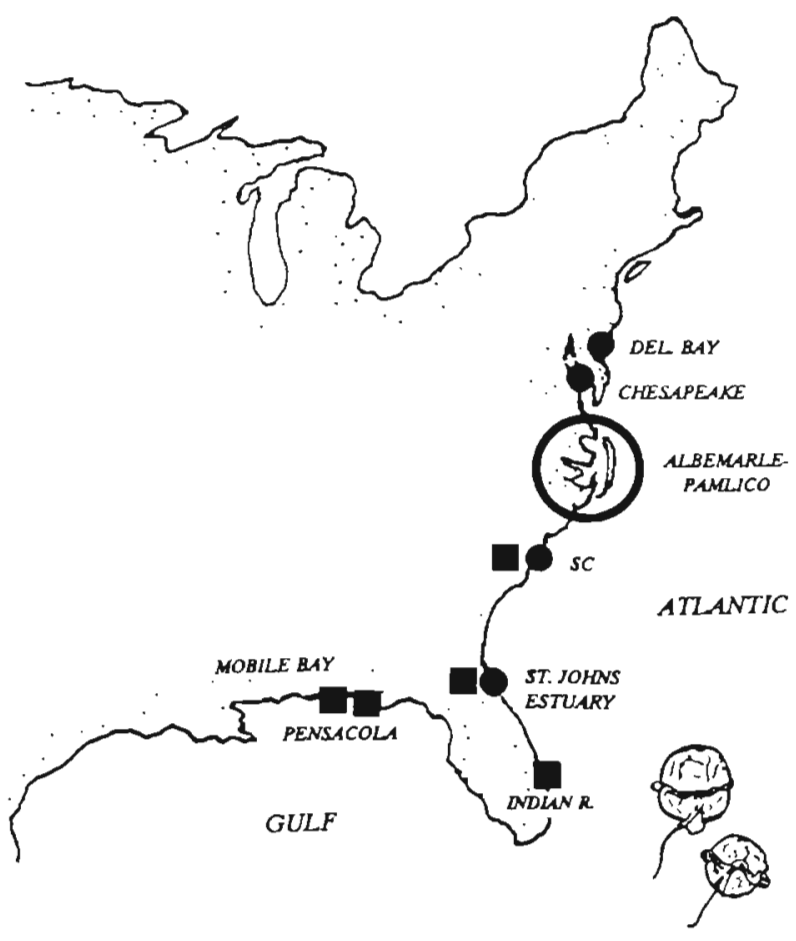

Fig. 3. Known geographic range of toxic ambush-predator dinoflagellates including Pfiesteria piscicida (circles; open circle designates the Albemarle-Pamlico region) and a second, more subtropical Pfiesteria-like species (squares). The map designates locations where TFVCs have been identified, and where potential toxicity has been verified using bioassays with tilapia; sites where confirming toxicity bioassays have not yet been completed are not shown, but lie within the indicated geographic range. These dinoflagellates have been tracked to known sites of fish kills and ulcerative disease from our northernmost sampling station to date (Indian River, Delaware), throughout most estuaries of the Albemarle-Pamlico Estuarine System (open circle) to our most southwestern site (Mobile Bay, Alabama), with apparent species overlap along the southern U.S. Atlantic Coast

we documented a hybrid striped bass kill in an aquaculture facility at ca $0 \mathrm{ppt}$ (total hardness $=20 \mathrm{mg} \mathrm{l}^{-1}$; Table 2). The water used in the aquaculture facility originated from the calcium-rich Castle Hayne coastal aquifer. The dinoflagellate was believed to have been transported to the ponds either by waterfowl, on estuarine foam carried by wind, or from previous use of Pamlico Estuary water. Among the salinities tested, $15 \mathrm{ppt}$ was optimal for growth and activity of TZs (significantly higher than at other salinities tested; $p<0.02$; Fig. 4). Fish death occurred at $10 \mathrm{ppt}$ or higher in dinoflagellate-exposed treatments during the $16 \mathrm{~d}$ experiment. On Day 17 the fish were fed in all tanks, and 8 of 9 total fish from the 5 pt replicate aquaria died by Day 20, as compared to no fish death in the 5 ppt controls 
Table 3. Species of finfish and shellfish that have been killed in natural habitat or culture bioassays containing active stages of Pficsteria piscicida. Asterisks (") undicate confirming aquarium bioassays on adults (A), pediveligers (P), or juveniles ( $\mathrm{J}$ ); mortality of remainung species occurred during field or aquaculture kills in which $P$. piscicida was implicated as the causative agent (based on quantification of toxic stages at $\geq 250 \mathrm{cells}^{-1}$ in water samples from the kills, and scanning electron microscopy to verify identification). The dinoflagellate has proven lethal to all tested finfish and shellfish

\author{
Native estuarine/marine species \\ American eel \\ Atlantic croaker \\ Atlantic menhaden \\ Bay scallop \\ Black grouper \\ Blue crab \\ Channel catfish \\ Eastern oyster \\ Hogchoker \\ Killifish (mummichog) \\ Largemouth bass \\ Mosquitofish \\ Naked goby \\ Northern quahog (littleneck clam) \\ Pinfish \\ Red drum. \\ Redear sunfish \\ Sheepshead \\ Southern flounder \\ Spot \\ Spotted sea trout \\ Striped bass \\ Striped mullet \\ White perch
}

Exotic (introduced) species

Clownfish (clown anemonefish)

Goldfish

Guppie

Hybrid striped bass

Tilapia

\author{
Anguilla rostrata Lesueur \\ Micropogonias undulatus L. \\ Brevoortia tyrannus Latrobe \\ Argopecten irradians Lamarck \\ Mycteroperca bonaci Poey \\ Callinectes sapidus Rathbun \\ Icatalurus punctatus $\mathrm{L}$. \\ Crassostrea virginica Gmelin \\ Trinectes maculatus Block \& Schneider \\ Fundulus heterocIitus L. \\ Micropterus salmoides Lacepede \\ Gambusia affinis Baird \& Girard \\ Gobiosoma bosc Lacepede \\ Mercenaria mercenaria Linne \\ Lagodon rhomboides L. \\ Sciaenops ocellatus L. \\ Lepomis microlophys $\mathrm{L}$. \\ Archosargus probatocephalus Walbaum \\ Paralichthys lethostigma Jordan \& Gilbert \\ Leiostomus xanthuris Lacepede \\ Cynoscion nebulosus Cuvier \\ Morone saxatilis Walbaum \\ Mugil cephalus L. \\ Morone americana Gmelin
}

A

$A$

$A_{1}$

$\cdot \mathrm{A}$

A

*A

A

$\cdot P^{a}$

A

'A

$A^{b}$

$\cdot A$

A

J, A

A

$\cdot \mathrm{A}$

$A^{b}$

A

$\cdot A$

$\cdot A$

A

A

A

$\cdot \mathrm{A}$

Amphiprion percula Lacepede

Carrasius auratus L.

Poecilia reticulata Peters

Morone saxatilis $\times$ Morone chrysops Rafinesque

Oreochromis aureus Steindachner, Oreochromis

mossambica Peters, Tilapia nolotica L.

$$
\begin{aligned}
& \cdot A \\
& \cdot A \\
& \cdot A \\
& \cdot A, J \\
& \cdot A
\end{aligned}
$$

${ }^{a}$ Confirming bioassays on eastern oyster pediveliger larvae were completed by G. Krantz with J.M.B. and H.B.G. (Krantz et al. 1994)

'Largemouth bass and redear sunfish are considered freshwater species, but they were found in slightly brackish waters

Pfiesteria piscicida also was capable of lethal activity across a broad gradient of light intensity. The dinoflagellate showed comparable toxicity to fish across the tested range of available light with no apparent optimum (Fig. 5). Abundances of the 4 most common stages (TZs, gametes, amoebae and cysts) were highly variable among replicates within each light treatment. The maximum for each active stage occurred at a different light intensity (considering median cell densities among replicates: TZs, $25 \mu$ Ein $\mathrm{m}^{-2} \mathrm{~s}^{-1}$; gametes, $200 \mu$ Ein $\mathrm{m}^{-2} \mathrm{~s}^{-1}$, the highest light level tested; amoebae, $0.2 \mu$ Ein $\mathrm{m}^{-2}$ $\mathrm{s}^{-1}$ ), suggesting a selective tendency for optimal light levels among stages. Recent documentation of 'cleptochloroplasts' in the vegetative flagellated stage of $P$. piscicida (i.e. chloroplasts retained for use after digestion of photosynthetic algal prey; Steidinger et al. 1995) points to a mechanism by which this alga could benefit from a 'borrowed' photosynthetic mode of nutrition. We maintained cultures of TZs $\left(<5000\right.$ cells ml $\left.{ }^{-1}\right)$ for several days when supplied with microalgae (diatoms or small cryptomonad, green, or chrysophyte flagellates) as a food resource, but toxicity gradually decreased and reversions to nontoxic zoospores or transformations to amoebae and cysts increased unless live fish or their fresh tissues were added (Burkholder et al. 1993, 1995).

\section{DISCUSSION}

This research implicates toxic ambush-predator dinoflagellates as major causative agents of fish kills of the southeastern United States. Pfiesteria piscicida proved lethal to all 19 bioassayed species of finfish and shellfish. An additional 13 species were involved in 


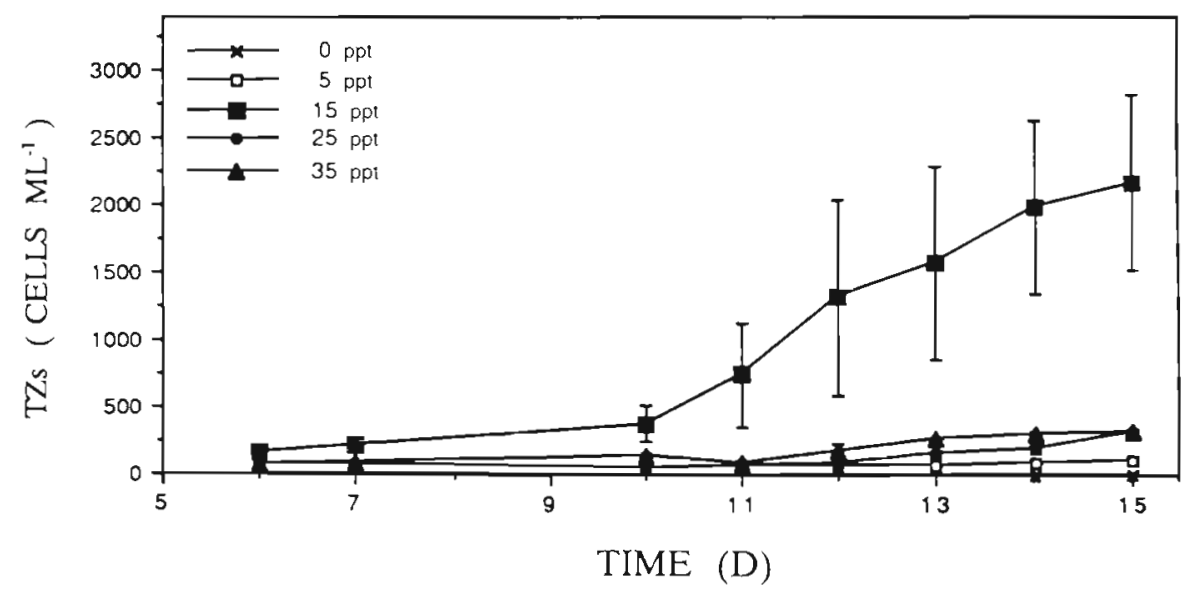

Fig. 4. Response of Pfiesteria piscicida to a salinity gradient imposed by mixing Instant Ocean salts with a (soft) wellwater source (alkalinity ca $4 \mathrm{mg} \mathrm{l}^{-1}$ ). Data are given as means $\pm 1 \mathrm{SE}(\mathrm{n}=3)$. The large error bars associated with the 15 ppt curve reflect the delayed response of the dinoflagellate in 1 of the 3 replicate aquaria for that treatment

field or aquaculture kills associated with active TZ populations. These data demonstrate that, unlike other known ambush predators (Spero 1982, Ucko et al. 1994), P. piscicida is a 'generalist' which targets a wide array of finfish and shellfish species. It could be easily overlooked in fish kills because the TZs closely resemble other small, nontoxic species (e.g. Campbell 1973, Spero 1982); they may be pigmented by retaining chloroplasts from algal prey (Steidinger et al. 1995), but otherwise they are colorless or light brown and, hence, readily blend with their turbid surroundings. Recognition of ambush-predator dinoflagellates is further confounded because amoeboid stages in preserved material often resemble organic debris (Burkholder et al. 1995); in addition, the small flagellated forms tend to preserve poorly in fixatives that are used routinely for phytoplankton analysis (Spero 1982, Burkholder 1992).
Apart from the dinoflagellate's cryptic appearance and behavior, the extent of its involvement in kill events likely has been underestimated because of difficulty in reaching many kills to obtain water samples while fish were still dying, which is the optimal period for detecting the lethal TZs (Burkholder et al. 1992). We believe that this problem has been compounded because the behavior of affected fish has sometimes been mistaken as a response to low dissolved oxygen, rather than as suffocation from neurotoxin-induced muscle paralysis. For example, from NC DMF and NC DEM records preceding the discovery of Pfiesteria piscicida, kills of surface-dwelling Atlantic menhaden commonly were attributed to low oxygen stress even when dissolved oxygen was $>5 \mathrm{mg} \mathrm{l}^{-1}$ in the upper water column (NC DEHNR unpubl. records). In other cases, kills were often sampled several days after fish

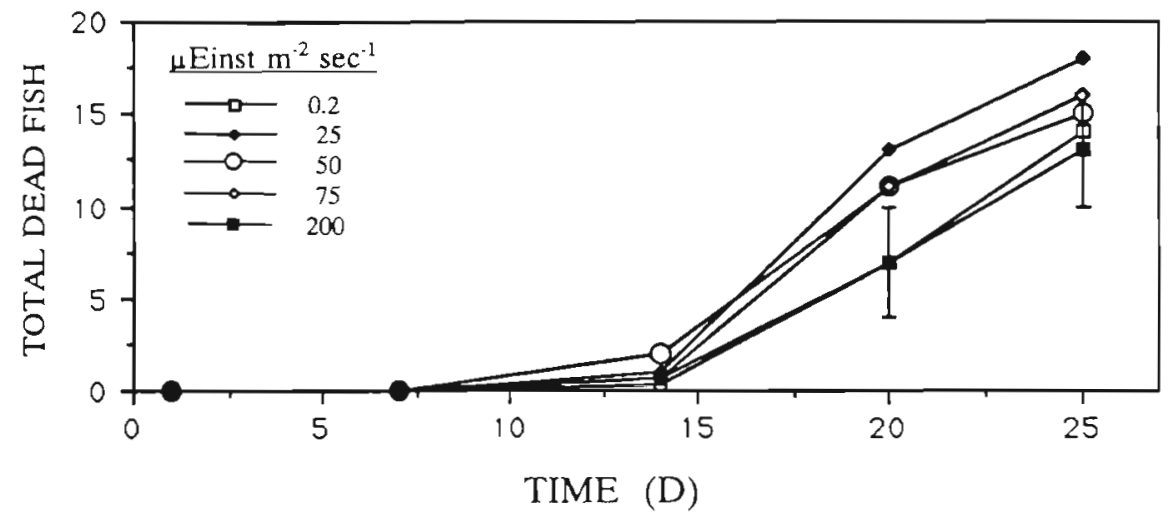

Fig. 5. Toxicity of Pfiesteria piscicida to test tilapia across a light gradient from $0.2 \mu$ Ein $\mathrm{m}^{-2} \mathrm{~s}^{-1}$ (darkness except for all but 1 to 2 min at $20 \mu$ Ein $\mathrm{m}^{-2} \mathrm{~s}^{-1}$, per $24 \mathrm{~h}$ period) to $200 \mu$ Ein m$^{-2} \mathrm{~s}^{-1}\left(12: 12 \mathrm{~h}\right.$ light: dark cycle using halogen tubes, $\left.20^{\circ} \mathrm{C}\right)$. Data are given as means $\pm 1 \mathrm{SE}$ of the fish killed (of 18 total fish added) in each replicate aquarium after the time indicated ( $\mathrm{n}=3$ ). Note that the dinoflagellate became slightly more toxic at $25 \mu \mathrm{Ein} \mathrm{m}^{-2} \mathrm{~s}^{-1}$ after $20 \mathrm{~d}$ ( $\mathrm{p}<0.045$ for each date at 20 and $25 \mathrm{~d}$ ) but, in general, lethal effects were comparable among treatments 
death; hence, hypoxic upper waters could have resulted from decomposition of fish remains, or could have acted synergistically with the dinoflagellate's toxin(s) in contributing to additional fish death.

Prior to this study, the overall role of Pfiesteria piscicida in fish kills from North Carolina waters also was obscured by the lack of a central, organized data base of state records for estuarine and marine fish kills (currently in handwritten files at various branch offices within 2 divisions of NC DEHNR, and in an incomplete computerized data base), and by exclusion of data on causative factors in the available records unless collected by state personnel. Such lack of organized information about fish kills, partly resulting from insufficient funding to sustain innovative state programs or even to support timely sampling efforts (e.g. Miller et al. 1990), is widespread along U.S. coasts but worse in North Carolina than in any other state (Lowe et al. 1991, Adler et al, 1993). Given projected exponential population growth with associated water quality degradation in coastal areas (Holman 1993, Miller 1994), and current severe declines in wild fish stocks (NOAA 1992b, NC DMF 1993, Food \& Agriculture Organization 1994, Leavenworth 1994, NC DMF unpubl. records), this pervasive dearth of information points to a critical need for higher regulatory staff 'across' divisions and agencies to increase emphasis on fish kill assessment programs. In North Carolina and elsewhere, there is an equally pressing need for legislators to recognize that funding for such agencies must be increased to adequately support such programs (North Carolina Coastal Futures Committee 1994, Richissin 1994, World Resources Institute 1994). These steps would enable sampling of major fish kills while in progress so that pathogens, pollutants, and other contributory factors could be critically evaluated - information that must be obtained before management strategies can be developed to control these factors or mitigate their impacts.

At present, there is insufficient information to track Pfiesteria piscicida through geological time, or to evaluate whether its toxic outbreaks are increasing in frequency or aerial extent. Species-specific molecular markers (work in progress) will enable us to assess the dinoflagellate's long-term activity from cyst remains in cores from estuarine sediments. Although its toxic activity prior to May 1991 cannot be confirmed, some unexplained sudden-death kills in the Pamlico and Neuse dating back to 1985 (first year of consistent state records on phytoplankton abundance during fish kills) may have been linked to it. During that time the TZ stage was identified by state biologists (K. Lynch, NC DEM, pers. comm.). as 'Gymnodinium aurantium' (nomen nudum), a name unofficially given by Campbell (1973). The alga was assumed to be an incidental nontoxic species, and was recorded in fish kill records only if it comprised $8 \%$ or more of the totalphytoplankton biovolume. Analysis of NC DEM records revealed that ' $G$. aurantium' generally was low or subdominant in abundance relative to other phytoplankters $(<10 \%$ of the total phytoplankton biovolume as zoospores) except during fish kills, when this dinoflagellate (presumed TZ stage) contributed $18 \pm 11 \%$ of the total biovolume while representing only $9 \pm 9 \%$ of the total cell number (means $\pm 1 \mathrm{SE}$; Table 4).

From cursory sampling of sudden-death fish kill areas in Florida (July 1993 survey by colleagues K. Steidinger \& J. Landsberg with J.M.B.), the presence of Pfiesteria piscicida or a second Pfiesteria-like species was established in 7 of 10 eutrophic, known fish kill sites visited over a $4 \mathrm{~d}$ period that was spent mostly in transit. This information, along with confirmation of Pfiesteria-like species from samples provided by colleagues in Delaware, Maryland, Virginia, South Carolina, and Alabama, indicates that toxic ambushpredator dino-flagellates are common in shallow eutrophic estuaries throughout the mid-Atlantic and southeastern United States. The eurythermal, euryhaline character of $P$. piscicida increases the likelihood for widespread distribution of this species and its close relatives in other warm temperate and subtropical regions.

Pfiesteria piscicida was implicated as the causative agent of ca $50 \%$ of the major fish kills annually in the Neuse and Pamlico Estuaries from 1991 through 1993. Beyond the obvious acute effects manifested in fish kills, however, the role of toxic ambush-predator dinoflagellates in sublethal adverse impacts on fishery resources and other trophic levels merits serious consideration in future research. For example, within the past decade the Albemarle-Pamlico Estuary has experienced severe outbreaks of ulcerative skin and shell diseases among fish species (e.g. Atlantic menhaden, spot, Atlantic croaker, American eel, southern flounder, blue crab; Mather 1988, Levine et al. 1990, Miller et al. 1990). Among the most prevalent finfish diseases is ulcerative mycosis (Noga 1993), formerly attributed to fungal infection, wherein a mixed community of opportunistic fungal/bacterial pathogens partially colonizes deep open sores from the epidermis inward but generally not down to the lesion base (Noga et al. 1988). Fish species inhabiting low to moderate salinity areas have been afflicted by such diseases (Levine et al. 1990). During late spring - early summer 1994, flagellated stages of $P$. piscicida were common in the water column (ca 200 cells $\mathrm{ml}^{-1}$ ), and amoeboid stages formed a thin brownish ooze on fishermen's pound nets (J.M.B. \& H.B.G. unpubl. data). Many finfish sampled from these nets had open bleeding ulcerations (sore diameter 1 to $4 \mathrm{~cm}$; H.B.G., J.M.B. \& N. Deamer- 
Table 4. 'Historical record' of major fish kills potentially linked with the TZ stage of Pfiesteria piscicida from September 1985 to early May $1991^{\text {d }}$

\begin{tabular}{|c|c|c|c|c|}
\hline & Month & Location & Taxa affected & $\mathrm{TZs}^{\mathrm{a}}$ \\
\hline \multirow[t]{3}{*}{1985} & Sep & New River & Fish species & $\begin{array}{l}1400(<1 \%) \\
3 \% \text { total BV }\end{array}$ \\
\hline & Sep & Neuse: Wildlıfe Ramp & Fish species & $\begin{array}{l}2270(4 \%)_{i} \\
24 \% \text { total BV }\end{array}$ \\
\hline & Sep & Neuse: Trent River Bridge & Fish species & $\begin{array}{l}2620(3 \%)_{i} \\
11 \% \text { total BV }\end{array}$ \\
\hline 1986 & Aug & Pamlico: South Creek & Crab species & $\begin{array}{l}350 \mathrm{ml}^{-1}(<1 \%) \\
13 \% \text { total BV }\end{array}$ \\
\hline \multirow[t]{2}{*}{1987} & Jul & Pamlico: Bayview ${ }^{\mathrm{b}}$ & Fish species & $\begin{array}{l}6930 \mathrm{ml}^{-1}(34 \%) \\
20 \% \text { total BV }\end{array}$ \\
\hline & Aug & Pamlico: Pungo Creek ${ }^{\mathrm{b}}$ & Fish species & $\begin{array}{l}1310 \mathrm{ml}^{-1}(8 \%) \\
35 \% \text { total BV }\end{array}$ \\
\hline 1988 & May & Pamlico: Pungo Creek & $\begin{array}{l}\text { Mullet, trout, } \\
\text { menhaden }\end{array}$ & $\begin{array}{l}2820 \mathrm{ml}^{-1}(29 \%) ; \\
13 \% \text { total } \mathrm{BV}\end{array}$ \\
\hline \multirow[t]{7}{*}{1989} & Jun & Pamlico: Bond Creek & Fish, clams & $\begin{array}{l}395 \mathrm{ml}^{-1}(2 \%) \\
18 \% \text { total BV }\end{array}$ \\
\hline & Jun & Pamlico: Bayview & $\begin{array}{l}\text { Flounder, spot, } \\
\text { hogchokers }\end{array}$ & $\begin{array}{l}1750 \mathrm{ml}^{-1}(3 \%) \\
29 \% \text { total } \mathrm{BV}\end{array}$ \\
\hline & Jul & Neuse: Dawson Creek & Fish species & $\begin{array}{l}5240 \mathrm{ml}^{-1}(11 \%) \\
34 \% \text { total BV }\end{array}$ \\
\hline & Jul & Pamlico: South Creek ${ }^{b}$ & Fish, clams & $\begin{array}{l}945 \mathrm{ml}^{-1}(9 \%) \\
32 \% \text { total BV }\end{array}$ \\
\hline & Jul & Pamlico: South Creek & Clams & $\begin{array}{l}3320 \mathrm{ml}^{-1}(13 \%) \\
38 \% \text { total BV }\end{array}$ \\
\hline & Aug & $\begin{array}{l}\text { Neuse: Minnesott Beach/ } \\
\text { Cherry Point }{ }^{b}\end{array}$ & $\begin{array}{l}\text { Crabs, croaker, } \\
\text { Perch, menhaden, } \\
\text { Spot, flounder }\end{array}$ & $\begin{array}{l}1850-15000 \mathrm{ml}^{-1} \\
(18-32 \%)_{i}<60 \% \\
\text { total BV }\end{array}$ \\
\hline & Sep & Neuse: Minnesott Beach & Fish species & $\begin{array}{l}3960 \mathrm{ml}^{-1}(2 \%) \\
<7 \% \text { total BV }\end{array}$ \\
\hline \multirow[t]{3}{*}{1990} & Jul & $\begin{array}{l}\text { Pamlico: Ragged Point, } \\
\text { Bayview }\end{array}$ & $\begin{array}{l}\text { Menhaden, flounder, } \\
\text { hogchokers, spot }\end{array}$ & $\begin{array}{l}514-1029 \mathrm{ml}^{-1} \\
(14-18 \%)_{i} \\
2-3 \% \text { total BV }\end{array}$ \\
\hline & Aug & Pamlico: Pungo Creek & Fish, crabs & $\begin{array}{l}1572 \mathrm{ml}^{-1}(5 \%) \\
17 \% \text { total } \mathrm{BV}\end{array}$ \\
\hline & Aug & Pamlico: Bath Creek & Crabs & $\begin{array}{l}700 \mathrm{ml}^{-1}(1 \%) \\
9 \% \text { total BV }\end{array}$ \\
\hline \multirow[t]{2}{*}{1991} & May & $\begin{array}{l}\text { Pamlico: Bath Creek, } \\
\text { Durham Creek }\end{array}$ & Fish species & $\begin{array}{l}1050 \mathrm{ml}^{-1}(3 \%) \\
8 \% \text { total BV }\end{array}$ \\
\hline & May & Neuse: Marker no. 8 & Fish species & $\begin{array}{l}350 \mathrm{ml}^{-1}(<1 \%) \\
2 \% \text { total BV }\end{array}$ \\
\hline \multicolumn{5}{|c|}{$\begin{array}{l}\text { 'Data were provided by the NC DNRCD }(1987,1988,1989) \text { and by NC DEHNR }(1990 \mathrm{a}, 1991) \text {, wherein TZs of } P \text {. piscicida } \\
\text { (then unknown) were identified as the incidental species 'Gymnodinium aurantium'. Percent biovolume (BV): relative con- } \\
\text { tribution by TZs to the total phytoplankton community }\end{array}$} \\
\hline \multicolumn{5}{|c|}{${ }^{\mathrm{b}}$ The kill was also associated with low dissolved oxygen ( $\mathrm{ca} 3.0 \mathrm{mg} \mathrm{l}^{-1}$ ) in the bottom water } \\
\hline
\end{tabular}

Melia, from random sampling of 2 to 3 groups of 100 adult Atlantic menhaden with American eel, spot, Atlantic croaker, etc.; $30 \pm 2 \%$ in early May, $60 \pm 3 \%$ in late May, $98 \pm 1 \%$ in late June). In areas where lesions did not form over vital organs, they sometimes penetrated completely through the body leaving large gaping holes in the moribund but still swimming fish (also observed by Noga et al. 1988). The opportunistic nature of the fungal/bacterial colonizers indicated that an unknown initial stressor could have weakened the hosts' resistance. Repeated observations of damage to fish epidermis by $P$. piscicida in aquarium cultures led to clinical research that corroborated the toxin's role in forming the lesions involved in ulcerative 'mycosis' of Atlantic menhaden (Noga et al. 1995).

Whether certain fishing practices might indirectly contribute to toxic Pfiesteria piscicida outbreaks remains to be examined. In the mid-Pamlico Estuary, ulcerative disease incidence declined to $1 \%$ and fish kills ceased by mid-July 1994, shortly after intensive 
trawling operations moved downstream to the lower estuary and Pamlico Sound (H.B.G., J.M.B. \& N. Deamer-Melia unpubl. data, NC DEM and NC DMF unpubl. records). Trawlers had fished the mid-Pamlico from late winter to early July. Moreover, a drought from May to early August allowed formation of an unusually well-defined salt wedge with hypoxic bottom water that extended upstream to the city of Washington (NC DEM unpubl. records; Fig. 1, site 1). In the early to mid-growing season, trawling activities in some of the known dinoflagellate kill sites (P-enriched at mid-range salinity) could have helped stimulate $P$. piscicida by suspending benthic stages as well as other microbial pathogens, nutrients, toxic substances, and wounded fish into the water column. Cessation of trawling would have allowed the salt wedge to more effectively isolate benthic stages from viable fish populations in the upper water column. Dinoflagellate cysts are known to survive several years of anoxia, and excystment can occur in low-oxygen water (Anderson \& Keafer 1985, Anderson et al. 1987). Nonetheless, salt wedge-imposed density/chemical gradients could have slowed the excystment process, minimized detection of fish secreta, and impeded dinoflagellate movement from the sediment to surface waters. Further study will help clarify whether the timing of reduced fish disease/kills during a season when $P$. piscicida has usually been active, and shortly after trawlers moved to less favorable areas for the dinoflagellate (higher salinity, lower background nutrients), was only coincidental. Fish kills linked to $P$. piscicida did not recur in the mid-Pamlico until late August 1994 (H.B.G., J.M.B. \& N. Deamer-Melia unpubl. data; NC DEM and NC DMF unpubl. records).

Toxic ambush-predator dinoflagellates likely cause other chronic, insidious effects on fish recruitment and food resources. Our preliminary data indicate that Atlantic menhaden eggs do not hatch when TZs are abundant (unpubl. data of W. Hettler, National Marine Fisheries Service, Beaufort, NC, with H.B.G. \& J.M.B.), and that juvenile hybrid striped bass are more susceptible to the toxin(s) of Pfiesteria piscicida than adults (i.e. juveniles die more rapidly, and are affected by lower $T Z$ densities). These observations suggest that $a$ school of fish which successfully leaves a toxic outbreak area may have only escaped on a short-term basis. The narcotizing effects induced by the toxin on the closing reflex of adult bay scallops and oysters, and on the activity of oyster pediveliger larvae (Burkholder et al. 1992, Krantz et al. 1994), could result in greater susceptibility of these animals to predators. The toxin's sporadic 'speed' effect on zooplankton (more active, erratic swimming that includes head-on collisions with the culture vessel walls; Mallin et al. 1995) and blue crabs could enhance detection by predators, as well.
Adverse effects can also be extended to humans. In a laboratory setting, several cases of narcosis (hours) and lingering symptoms such as reversible Alzheimer'slike short-term memory loss and cognitive dysfunction (days to weeks), suppressed immune system function, respiratory distress, elevated hepatic enzyme activities, slight renal dysfunction, and autonomic and peripheral nervous system dysfunction (months to years) have occurred following chronic contact ( 6 to 8 wk) with water containing low to moderate densities of toxic stages ( $>2000 \mathrm{cells} \mathrm{ml}^{-1}$ ), or exposure to neurotoxic aerosols from these cultures (Glasgow et al. 1995). Apart from anecdotal information provided by local fishermen, carefully designed epidemiological studies are lacking to determine whether humans who frequent estuaries with toxic outbreaks might be adversely affected with subtle immune system suppression and other symtoms from chronic or acute exposure to toxin(s) from Pfiesteria piscicida.

Aside from stimulation by finfish, nutrient enrichment may contribute to maintenance of a watercolumn inoculum of nontoxic precursor stages to TZs. These stages would be positioned to respond rapidly to the presence of feeding schools of fish under calm conditions in poorly flushed upper tributaries, when wind and wave action were not available to suspend the benthic amoebae and cysts. Approximately $75 \%$ of the kills ( 14 of 19, from previous state records 1985 to early 1991) that were associated with potentially lethal densities of 'Gymnodinium aurantium' $(\geq 300$ cells $\mathrm{ml}^{-1}$ ) occurred in nutrient-enriched areas of the Pamlico (naturally P-rich sediments, with water-column and sediment $P$ augmented in some kill sites by $P$ mining, sewage, and other sources) and the Neuse (Cherry Point region). Similarly, between 1991 and 1993, 74\% of the field kills occurred in the Pamlico (10 kills) or the Cherry Point area of the Neuse (4 kills). Laboratory bioassays have indicated a direct stimulatory effect of phosphourus enrichment on growth of Pfiesteria piscicida's nontoxic zoospores (reverted from gametes) and amoebae, especially if supplemented with smaller flagellated algal prey (Burkholder et al. 1992, 1995, Burkholder \& Glasgow 1995). The dinoflagellate's apparent preference for nutrient-rich waters suggests that precursor stages to lethal TZs might be expected to proliferate in areas where nutrient loading directly stimulated their metabolism and/or indirectly enhanced growth by supporting blooms of smaller algae. Additional data in support of this hypothesis would present a powerful argument in favor of improved regulations to reduce nutrient loading to shallow, poorly flushed estuaries in warm temperate and subtropical regions that serve as optimal habitat for these widespread cryptic predators of targeted fish and other prey. 
Acknowledgements. Funding support for this research was provided by the National Science Foundation (grant OCE9403920); the Office of Sea Grant, NOAA, the U.S. Dept of Commerce (grant NA90AA-D-SG062), the UNC Sea Grant College (projects R/MER-17 and R/MBT-1A); the AlbemarlePamlico Estuarine Study (U.S. EPA National Estuary Program and NC DEHNR) through the UNC Water Resources Research Institute; the U.S. Marine Air Station at Cherry Point; the NC Agricultural Research Foundation (project 06034), the NC Agricultural Research Service (project 06188), the NCSU College of Agriculture \& Life Sciences, and the NCSU Department of Botany (E. Seneca). A. Glasgow's understanding and faith in the investigators greatly enriched this project. We are grateful for the help of many staff from NC DMF and NC DEM in providing algal samples from fish kills in estuarine habitat including $\mathrm{K}$. Miller, $\mathrm{K}$. Lynch, $\mathrm{J}$. Hawkins, K. West, J. Mulligan, R. Carpenter, V. Coleman, B. Adams, A. Hodge, M. Yount, M. Street, R. Tankard, and P Fowler. We thank B. J. Copeland, F. Cross, R. Dove, R. Hodson, B. Hettler, N. McNeil, M. Mallin, R. Mays, A. Powell, C. Sullivan, and $P$. Tester for providing information or samples that led to confirmation of Pfiesteria activity during estuarine and aquaculture fish kills. R. Dove, D. Phelps, B. Fritz, G. Evans, Y. Barber, and T. Quay helped establish volunteer efforts to sample kills, such as the Neuse River Foundation's Creek Keepers. D. Ormond offered his time and his boat to help obtain Pfiesteria samples and pound net data for fish ulcerations. K. Steidinger, J Landsberg, B. Anderson, R. Miller, H. Awetman, K. Sellner, D. Britburg, C. Pacey, C. Sullivan, and $B$. Lapointe helped in our effort to document the presence of Pfiesteria-like species outside North Carolina. D. Rainer and B. MacDonald contributed sound counsel in laboratory safety protocols. J. Sauber provided NC DEHNR data to strengthen our nutrient data in the vicinity of field fish kills; and K. Lynch, K. Miller, and V. Coleman helped provide a complete set of NC DEHNR data for estuarine fish kills and dinoflagellate abundance. Research assistance was contributed by V. Coleman, J. Compton, D. Briley, F. Johnson, L. (Taggett) Taylor, C. Harrington, M. McAuley and G. Morgan. $C$. Brownie counseled us on statistics; U. Blum reviewed photos; and B. J. Copeland, J. Hawkins, K. Miller, K. West, A. Lewitus, M. Mallin, P. Tester, S. Shumway, N. Deamer-Melia, M. Larsen, B. Touchette, E. Fensin, D. Briley, J. Compton, and E. Hannon kindly critiqued the manuscript. Finally, we thank B. J. Copeland, R. Waite, J. Wynne, C. Moreland, B. Graham, F. Cross, D. Moreau, R. Holman, B. Hogarth, R. Dove, M. Smith, B. Leslie, T Miller, and R. Mason, whose interest and support helped make this research possible.

\section{LITERATURE CITED}

Adler RW, Landman JC, Cameron DM (1993) The Clean Water Act 20 years later. National Resources Defense Council. Island Press, Washington, DC

Anderson DM, Keafer BA (1985) Dinoflagellate cyst dynamics in coastal and estuarine waters. In: Anderson DA, White AW, Baden DG (eds) Toxic dinoflagellates. Proceedings, Third International Conference on Toxic Dinoflagellates. Elsevier, New York, p 219-224

Anderson DM, Taylor CD, Armbrust EV (1987) The effects of darkness and anaerobiosis on dinoflagellate cyst germination. Limnol Oceanogr 32:340-351

Bovee EC, Sawyer TK (1979) Marine flora and fauna of the northeastern United States. Protozoa: Sarcodina: Amoebae. NOAA Tech Rep NMFS Circular 419. US Department of Commerce - NOAA NMFS, Washington, DC, p 1-57
Burkholder, JM (1992) Phytoplankton and episodic suspended sediment loading: phosphate partitioning and mechanisms for survival. Limnol Oceanogr 37: 974-988

Burkholder JM, Glasgow HB Jr (1994) The enriched life of an ambush predator: a new ichthyotoxic dinoflagellate in eutrophic estuaries (Abstract). In: Proceedings, 12th Biennial International Esturarine Research Federation Conference, Hilton Head, SC, p 16

Burkholder JM, Glasgow HB Jr (1995) Interactions of a toxic estuarine dinoflagellate with microbial predators and prey. Archiv Protistenk 145:177-178

Burkholder JM, Glasgow HB Jr, Noga EJ, Hobbs CW (1993) The role of a newly discovered toxic dinoflagellate in finfish and shellfish kills in the Neuse and Pamlico Estuaries. Albemarle-Pamlico Estuarine Study Rep No 93-08. NC DEHNR and US EPA National Estuary Program, Raleigh, p 1-58

Burkholder JM, Glasgow HB Jr, Steidinger KA (1995) Stage transformations in the complex life cycle of an 'ambush-

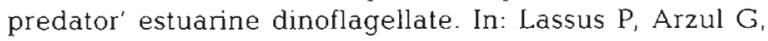
Erard E, Gentien P, Marcaillou C (eds) Harmful marine algal blooms. Elsevier, Amsterdam, p. 567-572

Burkholder JM, Noga EJ, Hobbs CW, Glasgow HB Jr, Smith SA (1992) New 'phantom' dinoflagellate is the causative agent of major estuarine fish kills. Nature 358:407-410; 360:768

Burkholder JM, Wetzel RG (1989) Epiphytic microalgae on natural substrata in a hardwater lake: seasonal dynamics of community structure, biomass and ATP content. Arch Hydrobiol (Suppl) 83:1-56

Campbell, PH (1973) Studies on brackish water phytoplankton. Sea Grant Publication UNC-SG-73-07. UNC Sea Grant Program, Chapel Hill

Copeland BJ, Hodson RG, Riggs SR (1984) The ecology of the Pamlico River, North Carolina: an estuarine profile. US Fish \& Wildlife Service Rep FWS/OBS-82/06. US Fish \& Wildlife Service, Washington, DC

Culotta E (1992) Red menace in the world's oceans. Science 257:1476-1477

Day RW, Quinn GP (1989) Comparison of treatments after an analysis of variance in ecology. Ecol Monogr 59:433-463

Dennison WC, Orth RJ, Moore KA, Stevenson JC, Carter V. Kollar S, Bergstrom PW, Batiuk RA (1993) Assessing water quality with submersed vegetation. BioSci 43:86-94

Epperly SP, Ross SW (1986) Characterization of the North Carolina Pamlico-Albemarle estuarine complex. NOAA Tech Memo NMFS-SEFC-175

Food \& Agriculture Organization (1994) Review of the state of world marine fishery resources. FAO Fish Tech Pap 335

Gill JL (1978) Design and analysis of experiments in the animal and medical sciences, Vol 1,2 and 3. Iowa State University Press, Ames

Glasgow HB Jr, Burkholder JM (1993) Comparative saprotrophy by flagellated and amoeboid stages of an ichthyotoxic estuarine dinoflagellate (Abstract). In: Abstracts, Sixth International Conference on Toxic Marine Phytoplankton, Nantes, France, October 1993. Ministere de Affaires Etrangeres, Nantes, p 87

Glasgow HB Jr, Burkholder JM, Schmecel DE, Tester PA, Rublec PA (1995) Insidious effects of a toxic dinoflagellate on fish survival and human health. $J$ Toxical environ Health (in press)

Holman R (1993) Evaluation of the APES area using population, land use and water quality information. Final Rep No 92-16. Albemarle-Pamlico Estuarine Study. NC DEHNR and US EPA National Estuary Program, Raleigh

Jaworski NA, Groffman PM, Keller AA, Prager JC (1992) A 
watershed nitrogen and phosphorus balance: the upper Potomac River basin. Estuaries 15:83-95

Krantz G, Burkholder JM, Glasgow HB Jr (1994) Response of oysters to a culture of toxin-producing 'phantom' dinoflagellates. Proceedings, Annual Meeting of the American Shellfish Association, Charleston (Abstract) April 1994 American Shellfish Association, Charleston, SC, p 24

Landsberg JH, Steidinger KA, Blakesley BA (1995) Fishkilling dinoflagellates in a tropical aquarium. In: Lassus $P_{1}$ Arzul G, Erard E, Gentien P, Marcaillou C (eds) Harmful marine algal blooms. Elsevier, Amsterdam, p 65-70

Leavenworth S (1994) Fishing for trouble: can North Carolina save a dying resource? Part 1 . Falling catches warn of a crisis at sea. News \& Observer, Raleigh, 28 August

Lee JJ, Hutner SH, Bovee EC (1985) An illustrated guide to the protozoa. Society of Protozoologists, Lawrence, $\mathrm{KS}$, p 460

Levine JF, Hawkins JH, Dykstra MJ, Noga EJ, Moye DW, Cone RS (1990) Species distribution of ulcerative lesions on finfish in the Tar-Pamlico River Estuary, North Carolina. Dis aquat Org 8:1-5

Lewitus AJ, Jesien RV, Kana TM, Burkholder JM, Glaskow HB Jr, May E (1995) Discovery of the 'phantom' dinoflagellate in Chesapeake Bay. Estuaries (in press)

Lowe JA, Farrow DRG, Pait AS, Arenstam SJ, Lavan EF (1991) Fish kills in coastal waters 1980 - 1989. NOAA Strategic Environmental Assessments Division, Rockville

Lund JWG, Kipling C, LeCren ED (1958) The inverted microscope method of estimating algal numbers and the statistical basis of estimates by counting. Hydrobiologia 11:143-170

Mallin MA (1994) Phytoplankton ecology in North Carolina estuaries. Estuaries 17:561-574

Mallin MA, Burkholder JM, Larsen LM, Glasgow HB Jr (1995) Response of two zooplankton grazers to an ichthyotoxic estuarine dinoflagellate. J Plankton Res 17:351-363

Mallin MA, Paerl HW (1992) Effects of variable surface irradiance on phytoplankton productivity in shallow estuaries. Limnol Oceanogr 37:54-62

Mather T (1988) Fishermen never heard of fish dying 'way back yonder.' News \& Observer, Raleigh, 18 September

Miller GT Jr (1994) Living in the environment, 8th edn. Wadsworth, Belmont, CA

Miller KH, Camp J, Bland RW, Hawkins JH III, Tyndall CL, Adams BL (1990) Pamlico Environmental Response Team Report (June-December 1988). NC DEHNR, Wilmington

NOAA (National Oceanographic \& Atmospheric Administration) (1992a) Local climatic data - weekly and monthly summaries for Beaufort, North Carolina, and water temperature data for Beaufort Inlet. National Environmental Satellite, Data and Information Service (W Hettler), Beaufort

NOAA (1992b) Status of fishery resources of the southeastern United States for 1991 NOAA Tech Memorandum NMFS-SEFSC-306. NOAA-NMFS, Miami

NOAA (1993) Local climatic data - weekly and monthly summaries for Beaufort, North Carolina, and water temperature data for Beaufort Inlet. National Environmental Satellite, Data and Information Service (W Hettler), Beaufort

Noga EJ (1993) Fungal diseases of marine and estuarine fishes. In: Couch JA, Fournie JW (eds) Pathobiology of marine and estuarine organisms. CRC Press, Boca Raton, p 85-100

Noga EJ, Levine JF, Dykstra MJ, Hawkins JH (1988) Pathology of ulcerative mycosis in Atlantic menhaden, Brevoortia tyrannus. Dis aquat Org 4:189-197
Noga EJ, Smith SA, Burkholder JM, Hobbs CW, Bullis RA. (1993) A new ichthyotoxic dinoflagellate: cause of acute mortality in aquarium fishes. Vet Rec 133:96-97

Noga EJ, Khoo L, Stevens JB, Fan Z, Burkholder JM (1995) Novel toxic dinoflagellate causes epidemic disease in estuarine fish. Mar Pollut Bull (in press)

North Carolina Coastal Futures Committee (1994) Charting a course for our coast - a report to the Governor. NC DEHNR, Raleigh

NCDNRCD (North Carolina Department of Natural Resources \& Community Development) (1987) 1986 algal bloom reports. NC DEM - Water Quality Section, Raleigh

NC DNRCD (1988) 1987 algal bloom reports. NC DEM Water Quality Section, Raleigh

NC DNRCD (1989) 1988 algal bloom reports. NC DEM Water Quality Section, Raleigh

NC DEHNR (North Carolina Department of Environment, Health \& Natural Resources) (1990a) 1989 algal bloom reports. NC DEM, Raleigh

NC DEHNR (1990b) Water quality progress in North Carolina: 1989-1990 305(b) report. NC DEHNR, Raleigh

NC DEHNR (1991) 1990 algal bloom reports. NC DEM, Raleigh

NC DEHNR (1992) 1991 algal bloom reports. NC DEM, Raleigh

NC DMF (North Carolina Division of Marine Fisheries) (1993) Description of North Carolina's coastal fishery resources, 1972-1991. NC DMF, Morehead City

Potvin C, Lechowicz MJ (1990) The statistical analysis of ecophysiological response curves obtained from experiments involving repeated measures. Ecology 71: $1389-1400$

Richissin T (1994) Fishing for trouble: can North Carolina save a dying resource? Part 2. Despite signs of disaster, state slow to act. News \& Observer, Raleigh, 30 August

Rudek J, Paerl HW, Mallin MA, Bates PW (1991) Seasonal and hydrological control of phytoplankton nutrient limitation in the Neuse River Estuary, North Carolina. Mar Ecol Prog Ser 75:133-142

SAS Institute, Inc (1987) SAS/STAT guide for personal computers. Version 6. SAS Institute, Inc, Cary, NC

Smayda TJ (1989) Primary production and the global epidemic of phytoplankton blooms in the sea: a linkage? In: Cosper, EM, Bricelj, VM, Carpenter, EJ (eds) Novel phytoplankton blooms. Coastal and Estuarine Studies No 35. Springer-Verlag, New York, p 449-484

Smayda TJ (1992) Global epidemic of noxious phytoplankton blooms and food chain consequences in large ecosystems. In: Sherman, K, Alexander, LM, Gold, BD (eds) Food chains, models and management of large marine ecosystems. Westview Press, San Francisco, p 275-307

Smith SA, Noga EJ. Bullis RA (1988) Mortality in Tilapia aurea due to a toxic dinoflagellate bloom (Abstract). ProcThird Int Colloq Pathol Marine Aquacul, Gloucester Point, June 1988. Colloquium of Pathology in Marine Aquaculture, Gloucester, VA, p $167-168$

Spero HJ (1982) Phagotrophy in Gymnodinium fungiforme (Pyrrhophyta) : the peduncle as an organelle of ingestion $J$ Phycol 18:356-360

Stanley DH (1987) Water quality in the Pamlico River Estuary, 1986 Technical Report 87-01, Institute for Coastal and Marine Resources. East Carolina University, Greenville

Stanley DH (1992) Historical trends - water quality and fisheries: Albemarle-Pamlico SoundsUniversity of North Carolına Sea Grant College Program Publication UNC-SG92-04. UNC Sea Grant, Raleigh

Steidinger KA, Truby EW, Garrett JK, Burkholder JM (1995) The morphology and cytology of a newly discovered toxic 
dinoflagellate. In: Lassus P, Arzul G, Erard E, Gentien P, Marcaillou $C$ (eds) Harmful marine algal blooms. Elsevier, Amsterdam, p 83-87

Tester PA, Stumpf RP, Vukovich FM, Fowler PK, Turner JT (1991) An expatriate red tide bloom: transport, distribution, and persistence. Limnol Oceanogr 36: 1053-1061

Ucko M, Geresh S, Simon-Berkovitch B, Arad (Malis) S (1994)

This article was submitted by J. M. Lawrence (Senior Editorial Advisor), Tampa, Florida, USA
Predation by a dinoflagellate on a red microalga with a cell wall modified by sulfate and nitrate starvation. Mar Ecol Prog Ser 293-298

Vollenweider RA (ed) (1974) A manual for measuring primary production in aquatic environments. IBP Handbook No 12. FA Davis Company, Philadelphia

World Resources Institute (1994) Environmental almanac. Houghton Mifflin Company, Boston

Manuscript first received: August 16, 1995

Revised version accepted: January 18, 1995 